\title{
Strontium, boron, oxygen, and hydrogen isotope geochemistry of brines from basal strata of the Gulf Coast sedimentary basin, USA
}

\author{
Eva P. Moldovanyi, ${ }^{1}$ LYNn M. WALter, ${ }^{2}$ and Lynton S. LAND ${ }^{3}$ \\ 'Amoco Production Company, P.O. Box 3092, Houston, TX 77253 USA \\ ${ }^{2}$ Department of Geological Sciences, The University of Michigan, 1006 C.C. Little Building, Ann Arbor, MI 48109 USA \\ ${ }^{3}$ Department of Geological Sciences, The University of Texas, Austin, TX 78712 USA
}

\begin{abstract}
Significant spatial heterogeneities exist in the stable isotopic composition of saline formation waters from reservoirs of the Smackover Formation (Upper Jurassic). We focused on the southwest Arkansas shelf, a structurally simple portion of one of the interior basins of the northern Gulf Coast sedimentary basin. Here, faulting and facies changes juxtapose dominantly oolitic carbonate strata against basal evaporites, red beds, and siliciclastics, as well as metamorphosed basement rocks. Brines from this area have exceptionally high $\mathrm{Br}$ and alkali element concentrations and have spatially heterogeneous hydrogen sulfide concentrations. Strontium, boron, oxygen, and hydrogen isotope compositions exhibit coherent relations with other aspects of brine geochemistry. $\mathrm{Sr}$ isotope compositions range from those expected for carbonates and evaporites deposited from Jurassic seawater (0.7071) to radiogenic ratios as high as 0.7107 . Generally, most radiogenic $\mathrm{Sr}$ isotope values are associated with $\mathrm{H}_{2} \mathrm{~S}$-rich waters which also have elevated alkali element $(\mathrm{Li}, \mathrm{B}, \mathrm{K}, \mathrm{Rb})$ concentrations. These alkali element-rich waters are associated with portions of the South Arkansas fault system which reach basement.

Boron isotope compositions are similarly heterogeneous, ranging from values of +26 to $+50 \%$. Brines with highest $B$ contents are most depleted in ${ }^{11} B$, consistent with boron input from brines generated from high-temperature siliciclastic diagenetic reactions. Normalizing $\mathrm{B}$ contents to $\mathrm{Br}$ in the brines reveals a reasonable mixing trend between a Dead Sea-type composition and Texas Gulf Coast-type shale/sand reservoir waters.

Oxygen and hydrogen isotope data exhibit regional variations which are controlled by meteoric water invasion along the northern limb of the southwest Arkansas Fault, which has surface expression. Although oxygen isotope compositions are often near equilibrium with respect to reservoir carbonate, it is more difficult to ascribe trends in $\delta \mathrm{D}$ values to local water-rock interaction. The stable isotope trends can be explained either in terms of an evolved marine evaporite brine or a water evolved via water-rock interaction, and mixing with meteoric water in the vicinity of the southwest Arkansas Fault. Spatial heterogeneity in isotopic composition of formation waters from this relatively restricted study area suggests that assumptions of a homogeneous $\mathrm{Sr}$ reservoir in dating regional mineralization events require careful assessment in ancient systems.
\end{abstract}

\section{INTRODUCTION}

ALTHOUGH THE IMPORTANCE of subsurface brines in processes such as hydrocarbon migration and MVT-mineralization is widely recognized (e.g., SVERJENSKY, 1984; OLIVER, 1986; GE and GARVEN, 1989; BETHKE and MARSHAK, 1990), in most instances, the origins of water and solutes remain controversial. Salinity of brines has historically been attributed to halite dissolution (LAND and PREZBINDOWSKI, 1981; HANOR, 1987), retention or reflux of evaporatively concentrated seawater (RITTENHOUSE, 1967; CARPENTER, 1978), shale membrane filtration (GRAF, 1982), and/or evaporation of non-marine fluids (HARDIE, 1990). However, major element trends used to characterize the evolution of saline formation waters can rarely be explained by a single process. The data are often equivocal, thereby necessitating integration of elemental data with various isotope systematics to constrain the origin of fluids and to constrain the relative importance of diagenetic processes in different lithologic associations and basinal settings.

Fluid inclusions in sediment-hosted ore deposits and in late-stage diagenetic minerals in petroleum reservoir host rocks are commonly highly saline (up to $120 \mathrm{~g} / \mathrm{L} \mathrm{Cl}, 55 \mathrm{~g}$ / $\mathrm{L} . \mathrm{Na}$ and $20 \mathrm{~g} / \mathrm{L} \mathrm{Ca}$ ) and are generally interpreted to have been emplaced at moderate temperatures $\left(100-150^{\circ} \mathrm{C}\right)$ and pressures ( $<500$ bars; SVERJENSKY, 1984). The geochemical properties of fluid inclusions generally fall within the range of compositions measured in deep subsurface formation waters in the U.S. Gulf Coast sedimentary basin, especially those associated with Mesozoic strata (e.g., CARPENTER et al., 1974; CARPENTER and Trout, 1978; KHARAKA et al., 1987). Because of the geochemical similarities, these basal Gulf Coast formation waters are considered to be akin to mineralizing fluids, for which they often serve as proxies in ore-forming geochemical models (SVERJENSKY, 1984).

The Gulf Coast sedimentary basin, active since Upper Triassic/Jurassic time, is particularly pertinent to the study of brine elemental and isotopic evolution. Here, stratigraphic associations of carbonate reservoirs with siliciclastics and evaporites are very similar to those in many sediment-hosted ore deposits. In particular, Jurassic carbonate sediments (Smackover Formation) are associated with basal siliciclastics (Eagle Mills Formation), evaporites (Werner, Louann and Buckner formations), and metamorphosed basement. 
Smackover Formation waters are highly saline, and locally sulfide-rich. Furthermore, unlike waters in intracratonic settings, they have not been expelled from the basin and likely represent prograde geochemical evolution within the basin. Finally, unlike the "relict" hydrogeochemical system recorded in sediment-hosted ore deposits, we can observe directly spatial variability in isotopic composition in the fluids themselves. Regional, as well as temporal, variability in fluid geochemistry must be considered in dating mineralization events and in delimiting fluid migration pathways.

'The elemental chemistry of Smackover Formation waters in southwest Arkansas has been reported by CoLLINS (1974), Trout, (1974), CARPENTER and TROUT (1978), and MOLDOVANYI and WALTER (1992). Importantly, the brines are characterized by complex geochemical heterogeneities occurring on a relatively small spatial scale. These heterogeneities are regionally systematic and have been modeled in terms of four major processes: evaporative concentration of seawater, meteoric recharge, thermochemical sulfate reduction, and water-rock interactions in carbonate and siliciclastic strata (Trout, 1974; CARPENTER and TROUT, 1978; MOLDOVANYI and WALTFR, 1992). Yet, questions regarding the extent of halite recrystallization and dissolution and the extent of mixing with deeper-circulating fluids, or the role of thermochemical sulfate reduction, remained unanswered because of the equivocal trends in major element geochemistry. In this paper, strontium, boron, oxygen, and hydrogen isotopic compositions are integrated with data on major, minor, and trace element chemistry of brines and with the geochemistry of diagenetic phases to identify the mechanisms of brine evolution, to address the origin of water and solutes, and to better constrain fluid mixing endmembers.

The strontium isotopic composition of subsurface waters identifies sources of $\mathrm{Sr}$, constrains water-rock interactions, and may be used to trace the evolution and migration paths of fluids (ChAUDhURI, 1978; STARINSKY et al., 1983; STUEBER et al., 1984, 1987; MCNUTT et al., 1984; CHAUDHURI et al., 1987; RUSSELL et al., 1988; MCNUTT et al., 1987; MACK, 1990; STUEBER and WALTER, 1991). Sr isotope systematics have been applied to metal sulfides, gangue minerals, and host rocks in MVT ore deposits to determine sources of fluids and timing of mineralization (KESSEN et al., 1981; LANGE et al., 1983; MEDFORD et al., 1983; KESLER et al., 1988; NAKAl et al., 1990; BRANNON et al., 1991).

Oxygen and hydrogen isotopic data may also constrain fluid evolution by providing information regarding the source of water molecules and effects of water-rock interactions. In a classic study, ClAYTON et al. (1966) documented the oxygen and hydrogen isotopic composition of saline formation waters in the Illinois, Michigan, and Alberta sedimentary basins, and concluded that despite elevated salinities, subsurface waters in these basins were largely derived from local meteoric water. The oxygen isotope composition was considered to have evolved to more positive values via equilibration with carbonate minerals, while hydrogen isotope composition was relatively unaffected. More recently, the changes in oxygen and hydrogen isotopic compositions that accompany seawater evaporation have become recognized. At early stages of evaporation, residual waters can acquire a heavy isotopic composition, a trend which later reverses itself during more advanced stages of evaporation (SOFER and GAT, 1972; Holser, 1979; Pierre et al., 1984; KNAUTH and BeEunas, 1986). This trend has important implications for the origin of basinal waters because it permits waters with more negative $\delta \mathrm{D}$ and $\delta^{18} \mathrm{O}$ values to be generated by extreme evaporation of seawater as well as by meteoric water invasion.

Equilibration of water with feldspars and clay minerals can also affect water composition, sometimes producing significant depletion in the $\delta \mathrm{D}$ and enrichment of $\delta^{18} \mathrm{O}$ values of the residual fluid (YEH, 1980; SUCHECKI and LAND, 1983). Importantly, the low water-rock ratio characteristic of sedimentary strata can be coupled with massive mineralogical transformations during burial diagenesis, suggesting that the latter processes override any primary signal in shale-rich, siliciclastic sections of sedimentary basins, such as the upper Gulf Coast (e.g., YEH, 1980).

Application of boron isotopic systematics may permit advances to be made in distinguishing between marine and nonmarine solute sources. SwIHART et al. (1986) showed that marine evaporites may be differentiated from nonmarine evaporites because of the large difference in $B$ isotopic compositions of seawater and average continental crust. Seawater has an almost constant $\delta^{11} \mathrm{~B}(+40 \%)$, which is controlled by $\mathrm{B}$ adsorption onto detrital clays, weathering of oceanic crust, and clay authigenesis (SCHWARCZ et al., 1969; SPIVACK and EDMOND, 1987; SPIVACK et al., 1987). In contrast, B in the continental crust has lower $\delta^{11} \mathbf{B}(-8$ to $+2 \%$; SPIVACK et al., 1987; SwiHART et al., 1986). Moreover, because clays preferentially incorporate the lighter isotope, ${ }^{10} \mathrm{~B}$, they also tend to have a light boron isotopic composition $\left(\delta^{1 /} \mathrm{B}\right.$ $=+15 \%$ for desorbable $\mathrm{B}$ ) relative to seawater. MACPHERSON and LAND ( 1989 ) and VENGOSH et al. (1989, 1991a,b) have analyzed the boron isotopic composition of various natural waters from surface and sub-surface environments and noted large variations in $\delta^{11} \mathbf{B}$ which are attributed to the source of boron. Few formation waters and surface lakes analyzed to date have $\delta^{11} \mathrm{~B}$ values more positive than seawater. However, $\delta^{\prime \prime} \mathrm{B}$ significantly greater than $+40 \%$ is characteristic of Dead Sea brines. Because of the elevated salinity, unusually high $\mathrm{Br}$ content and similar overall geochemistry, the Smackover Formation waters have been likened to Dead Sea brines (CARPENTER and TROUT, 1978). It has been suggested that both waters have been partially derived from seawater evaporation and modified by later diagenetic processes including evaporite dissolution and recrystallization.

The oxygen, hydrogen, and strontium isotopic compositions of Smackover Formation waters in southwest Arkansas and central Mississippi have been investigated by KNAUTH et al. (1980), KHARAKA et al. (1987), and STUEBER et al. (1984), but isotopic trends have not been integrated with element chemistry, and the boron isotopic composition of these brines has not been reported. The present-day oxygen and hydrogen isotopic composition of Smackover Formation brines in MS has been modeled as seawater evaporated beyond halite facies, subsequently isotopically modified by exchange with the host rock and by mixing with meteoric water (KHARAKA et al., 1987). STUEber et al. (1984) measured the strontium isotopic composition of Smackover Formation brines in southwest Arkansas and found considerable variation in ${ }^{87} \mathrm{Sr} /{ }^{86} \mathrm{Sr}$ ratios, with values ranging from 0.7071 to 
0.7101 and most samples being significantly enriched in ${ }^{87} \mathrm{Sr}$ relative to Jurassic-age seawater. Enrichment in ${ }^{87} \mathrm{Sr}$ was attributed to detrital clastic mineral sources, but STUEBER et al. (1984) concluded that the observed regional heterogeneity was the result of random geochemical processes. The data we present will show that the geochemistry of Smackover Formation waters in southwest Arkansas indeed varies systematically in response to diagenetic and mixing events. The "ground truth" isotopic heterogeneity in formation waters of this relatively simple oolitic reservoir has important implications for regional hydrogeochemical modeling from $\mathrm{Sr}$ and other isotope systems in rock-based studies.

\section{THE STUDY AREA}

\section{Geological Framework}

The southwest Arkansas shelf is located near the updip limit of Jurassic sedimentation and is bounded by the east Texas, northern Louisiana, and central Mississippi salt basins, and the Sabine and Monroe uplifts. Figure 1 shows the study area in southwest Arkansas and gives the locations of samples analyzed for strontium, oxygen, and hydrogen isotopic composition relative to two dominant fault systems. The South Arkansas Fault system and the Louisiana State Line Graben were active during the Jurassic and are genetically related to deformation of the underlying Louann Salt (BISHOP, 1973). Both fault systems are potential sites for large-scale vertical migration of fluids (MCCAIG, 1988; HoOPER, 1991). Portions of the South Arkansas Fault system (in Miller, Lafayette, and Nevada counties) extend to the surface (HALEY et al., 1976). Faults associated with the Louisiana State Line Graben do not have surface expression but may extend to greater depths and may be related to older, previously existing zones of deformation (B1SHOP, 1973).
The Upper Smackover Formation mostly consists of oolitic and algal carbonate grainstones. However, in certain areas the high-energy carbonates grade into more carbonate mud-rich facies or into clastic facies (e.g., CHIMENE, 1976), and in structurally high locations Smackover Formation carbonates are completely absent (GREEN, 1989). The thicker, Lower Smackover Formation is made up of argillaceous and organic-rich mudstones and is thought to be a major source of hydrocarbons (e.g., SASSEN et al., 1987). The Smackover Formation is underlain by a thick sequence of clastics and evaporites (Fig. 2), which include, in ascending order from the basement, the redbeds of the Eagle Mills Formation, the Werner Anhydrite, the Louann Salt, which locally contains bittern salts (EuSTICE, 1990), and subarkosic sandstones of the Norphlet Formation. Shales and anhydrite of the Buckner and Haynesville formations directly overlie the Smackover Formation and the Jurassic section terminates with sands and shales of the Cotton Valley Group (BISHOP, 1967; DICKINSON, 1968; ColLINS, 1980).

Jurassic strata are relatively undeformed and consist of east-west striking beds gently dipping to the south. The Louann Formation lacks large salt domes, but salt swells in the southern portion of the study area probably contributed to local perturbations in Smackover Formation structure. The Louann Formation is absent west and north of the South Arkansas Fault in Miller County (ColLINS, 1980). Burial depths to the top of the Smackover Formation vary from approximately $1300 \mathrm{~m}$ in the north to $3250 \mathrm{~m}$ in the south and corresponding formation temperatures (obtained from petrophysical logs) range from 60 to $105^{\circ} \mathrm{C}$. These bottom hole temperatures may be affected by drilling conditions and drilling fluids and are therefore probably minimum values; however, they represent our best estimate of in situ reservoir conditions.

Diagenetic minerals in the Upper Smackover Formation occur as replacements of matrix or previously formed diagenetic phases, or as pore-filling cements, and include carbonates, sulfates, sulfides, and minor amounts of quartz, kaolinite, and clay minerals. The $\mathrm{Sr}$ isotopic composition of calcites, dolomites and $\mathrm{S}$ minerals has been integrated with petrographic relations to constrain strontium isotopic evolution

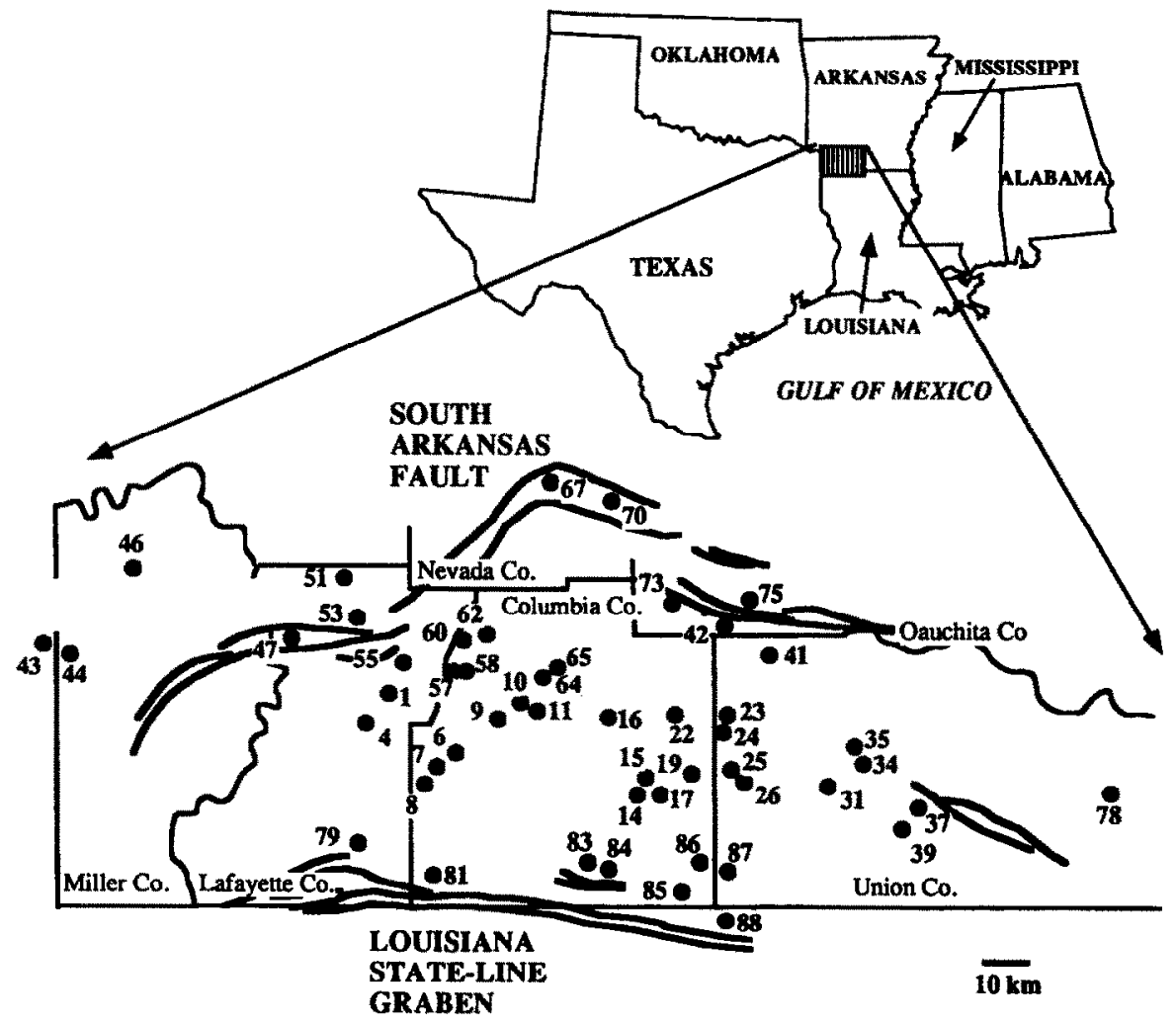

Fig. 1. Sample locations of brines selected for strontium, boron, oxygen, and hydrogen isotopic analyses. Numbers refer to sample ID in Table 1 . 


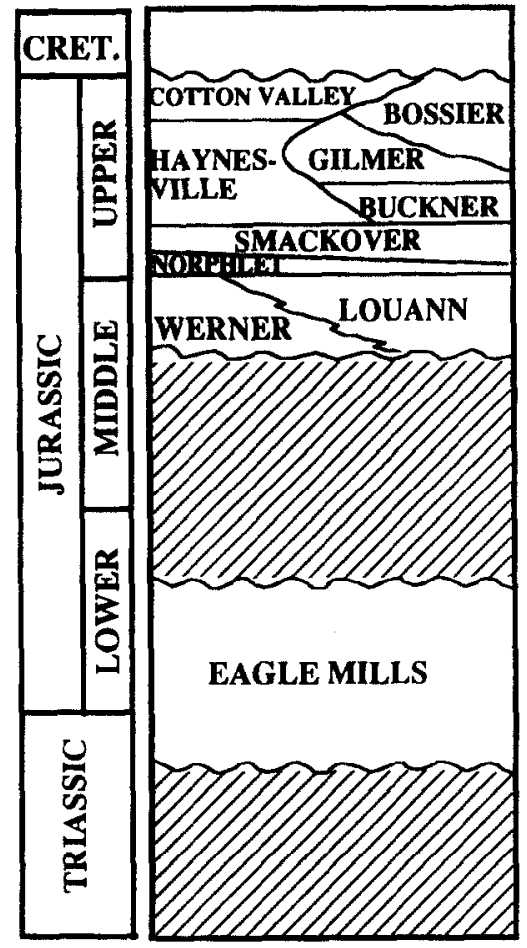

FlG. 2. Mesozoic stratigraphy, southwest Arkansas and northern Louisiana (after DiCKINSON, 1968). Not drawn to scale.

during progressive burial diagenesis (MOLDOVANYI et al., 1990; DWORKIN, 1991). Precipitation of calcite, anhydrite, and pyrite represent pre-compaction diagenetic processes ( $<500 \mathrm{~m}$ burial). Moderately radiogenic dolomite, sphalerite, and galena are intermediate in the diagenetic sequence, while fracture and vug-filling calcite, marcasite, native sulfur, and celestite are the latest diagenetic minerals precipitated from chemically evolved fluids during the deepest stages of burial. The enrichment in radiogenic $\mathrm{Sr}$ and the light-REE composition of latest-stage calcite cements in the Smackover Formation (MOLDOVANYI et al., 1990) is consistent with a source of fluids from clay-mineral transformation and feldspar diagenesis in siliciclastic strata or metamorphosed basement (AWwILLER and MACK, 1991). Overall, the chemistry of diagenetic phases suggests a trend toward higher ${ }^{87} \mathrm{Sr} /{ }^{86} \mathrm{Sr}$ ratios, more $\mathrm{H}_{2} \mathrm{~S}$ and metal availability, and increased influence of clastic diagenesis with increasing burial of the Smackover Formation.

\section{Elemental Geochemistry of Formation Waters}

Smackover Formation waters in southwest Arkansas are exceptionally saline brines and contain up to $365 \mathrm{~g} / \mathrm{L}$ TDS. Although evaporated seawater concentrated beyond halite facies but short of potash ( $\mathrm{Mg}$ - and $\mathrm{K}$-salt) facies may have contributed to these brines, geochemical relations indicate significant redistribution of solutes during extensive water-rock interaction. Brines are enriched in $\mathrm{Ca}$ and $\mathrm{Sr}$ and depleted in $\mathrm{Na}, \mathrm{K}, \mathrm{Mg}$, and $\mathrm{SO}_{4}$ with respect to evaporated seawater. The trends are consistent with, but not unique to, dolomitization and recrystallization of carbonates, sulfate dissolution/ precipitation, illitization of smectite, and albitization of Ca-rich feldspars (CARPENTER and TROUT, 1978; MOLDOVANYI and WALTER, 1992). Smackover Formation waters also have anomalously high bromide concentrations relative to evaporated seawater. Bromide enrichment in these formation waters could be due to seawater evaporation, to recrystallization of halite (STOESSELL and MOORE, 1983; LAND ct al., 1988), or to the dissolution of bittern salts deposited in this interior salt basin (LAND and PREZBINDOWSKI, 1981). However, Smackover Formation brines with elevated bromide content are not correspondingly enriched in elements associated with simple dissolution of bittern salts (e.g., K, Rb, B), thereby suggesting that $\mathrm{Br}$ enrichment occurred in response to the recrystallization of underlying Louann Salt (MOLDOVANYI and WALTER, 1992).

Lower salinity waters from certain Smackover reservoirs associated with the South Arkansas Fault have elevated $\mathrm{Cl} / \mathrm{Br}$ ratios (up to $2.5 \times$ higher than average) which are consistent with halite dissolution. Undersaturated meteoric waters were likely recharged to the Smackover Formation through faults having surface expression. Flevated $\mathrm{Cl} / \mathrm{Br}$ ratios in waters near the Louisiana State Line Graben are likely also related to proximity to the Louann Formation and to halite dissolution associated with water migration along faults, but there is no evidence of meteoric recharge.

A striking characteristic of Smackover Formation water geochemistry is the variability in $\mathrm{H}_{2} \mathrm{~S}$ concentrations. $\mathrm{H}_{2} \mathrm{~S}$-rich waters occur in the center of the study area, within a narrow east-west trending belt (Fig. 3a). Concentrations of dissolved sulfide range from $<10$ to $>600 \mathrm{mg} / \mathrm{L}$ and are highest at the western end of the study area, near the South Arkansas Fault system. Boron and alkali metals are typically enriched in $\mathrm{H}_{2} \mathrm{~S}$-rich waters and exhibit strong geochemical and spatial relations to $\mathrm{H}_{2} \mathrm{~S}$ content (Fig. 3b). The relations among $B$, alkali metals, and $\mathrm{H}_{2} \mathrm{~S}$ contents suggest that Smackover Formation brines have likely mixed with waters from deeper-seated strata undergoing siliciclastic diagenesis at higher temperatures (MOLDOVANYI and WALTER, 1992). Two major fault systems bounding the study area are the most likely large-scale fluid migration paths.

\section{TECHNIQUES AND ANALYTICAL RESULTS}

Formation water samples were collected and analyzed for major, minor, and trace element composition using field and laboratory techniques described in MOLDOVANYI and WALTER (1992). Samples identified numerically in Fig. 1 were selected for various isotopic analyses. Most samples are from reservoirs in oolitic carbonate reservoirs on the Arkansas shelf. Two samples, from east Texas (\#43) and west Arkansas ( $\# 44$ ), are from, or are in close proximity to, siliciclastic reservoirs of equivalent Jurassic age. The host rock at these sites consists of sandstones and redbeds eroded from an igneous intrusion in the immediate vicinity (GREEN, 1989). Results of Sr, $B, O$, and $\mathrm{H}$ isotopic analyses of Smackover Formation waters are given in Table 1.

Strontium isotope analyses were conducted on 49 filtered and acidified brine samples using a VG 354 thermal emission mass spectrometer at Washington University, following procedures described in POPP et al. (1986) and MoldovanYi et al. (1990). Brines were analyzed in triple or single collector mode and analytical uncertainty of all samples is better than $0.00005(2 \sigma) .{ }^{87} \mathrm{Sr} /{ }^{86} \mathrm{Sr}$ ratios were adjusted relative to the conventional ratio of 0.71014 for NBS-987. Actual measured values for NBS-987 were 0.71025 in triple collector Faraday mode and 0.71012 in single collector Daly mode.

Rubidium concentrations were determined by isotope dilution in single-collector mode using a Daly detector in pulse-counting mode and are precise to $0.5 \%$. Potential contributions to ${ }^{87} \mathrm{Sr}$ from in situ decay of $R b$, evaluated assuming a maximum age of $160 \mathrm{~m} . \mathrm{y}$., would decrease $\mathrm{Sr}$ isotope ratios by $9.5 \times 10^{-5}$ in waters with highest $\mathrm{Rb} /$ $\mathrm{Sr}$ and $0.7 \times 10^{-5}$ in waters with lowest $\mathrm{Rb} / \mathrm{Sr}$. As the majority of samples have contributions between 1.5 and $3.5 \times 10^{-5}$, similar to analytical uncertainty, in situ growth of ${ }^{87} \mathrm{Sr}$ is insignificant.

Eighteen water samples were selected from the subset for B isotopic analyses. Boron isotope analyses were performed at the University of Texas by trimethylborine distillation, and analysis as the Cs-metaborate ion (MACPHERSON, 1989). Boron isotopic data are given in standard " $\delta$ " notation, relative to NBS borate SRM 951 , and are reproducible to $\pm 0.5 \%$.

Oxygen and hydrogen isotopic analyses were performed at Arizona State University on 27 filtered samples collected in glass bottles with no head space. Oxygen isotopes were measured using the $\mathrm{CO}_{2}$ equilibration method (EPSTEIN and MAYEDA, 1953), with a reproducibility of $\pm 0.5 \%$. Oxygen isotopic ratios have been converted from measured activities to concentrations, correcting for compositional effects using equations of SOFER and GAT (1972). Hydrogen isotope ratios, measured using the heated capillary method described in KNAUTH and BEEUNAS (1986), are reported in concentration units and are precise to $\pm 1 \%$. $O$ and $H$ isotopic compositions are given in standard " $\delta$ " notation relative to SMOW. 

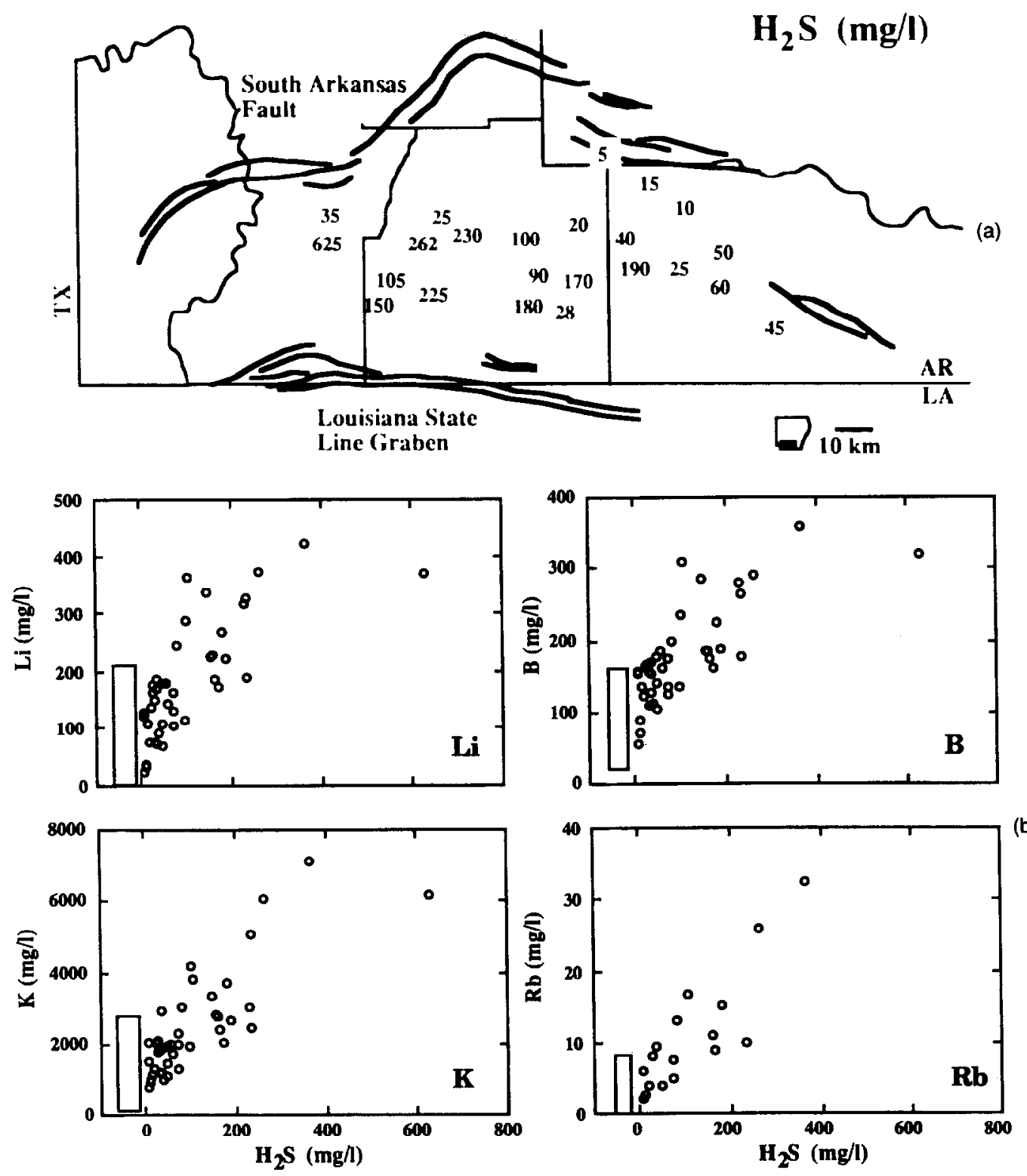

FIG. 3. (a) Concentration of dissolved $\mathrm{H}_{2} \mathrm{~S}(\mathrm{mg} / \mathrm{L}$ ) in Smackover Formation brines (modified from MoLDOVANYI and WALTER, 1992); (b) Li, B, K, and Rb concentrations vs. $\mathrm{H}_{2} \mathrm{~S}$ content in Smackover Formation brines. Range of $\mathrm{Li}, \mathrm{B}, \mathrm{K}$, and $\mathrm{Rb}$ concentrations for $\mathrm{H}_{2} \mathrm{~S}$-free samples is indicated by the boxed areas. Sulfide-free samples generally have lower and more homogeneous trace-element composition as compared to $\mathrm{H}_{2} \mathrm{~S}$-rich brines (modified from MOLDOVANYI and WALTER, 1992)

\section{STRONTIUM ISOTOPE COMPOSITION}

Strontium isotope ratios of Smackover Formation waters measured in this study range from 0.70743 to 0.71071 (Table 1) and are similar to the range observed by STUEBER et al. (1984). All samples are more radiogenic than Jurassic-age marine carbonate (0.7068 to 0.7072 ; BURKE et al., 1982) and considerable variation in ${ }^{87} \mathrm{Sr} /{ }^{86} \mathrm{Sr}$ ratios occurs within and between $\mathrm{H}_{2} \mathrm{~S}$-rich and $\mathrm{H}_{2} \mathrm{~S}$-free waters across the relatively small study area. $\mathrm{Sr}$ isotope ratios can vary dramatically among adjacent brine samples (Fig. 4a,b), although mean ${ }^{87} \mathrm{Sr} /{ }^{86} \mathrm{Sr}$ ratios of $\mathrm{H}_{2} \mathrm{~S}$-rich and $\mathrm{H}_{2} \mathrm{~S}$-free waters are not significantly different $(0.70898 \pm 0.00088$ and 0.70863 \pm 0.00060 , respectively). In both $\mathrm{H}_{2} \mathrm{~S}$-free and $\mathrm{H}_{2} \mathrm{~S}$-rich oo- litic carbonate reservoirs, ${ }^{87} \mathrm{Sr} /{ }^{86} \mathrm{Sr}$ ratios are independent of bromide content and other major ion concentrations, and show no trend with $\delta^{18} \mathrm{O}$ and $\delta \mathrm{D}$.

Within the $\mathrm{H}_{2} \mathrm{~S}$-rich belt, formation waters are generally more radiogenic than the $\mathrm{H}_{2} \mathrm{~S}$-free brines sampled north and south of the belt (Fig. 4a,b). A frequency plot of ${ }^{87} \mathrm{Sr} /{ }^{86} \mathrm{Sr}$ ratios in $\mathrm{H}_{2} \mathrm{~S}$-rich brines confirms the heterogeneous nature of these fluids and shows the even distribution of ${ }^{87} \mathrm{Sr} /{ }^{86} \mathrm{Sr}$ ratios (Fig. 4a). Formation waters from the western part of the study area are more radiogenic than brines sampled at the northeastern extension of the belt. This regional gradient is also apparent in $\mathrm{H}_{2} \mathrm{~S}$ and alkali element concentrations. Figure 5 shows the strong relation between ${ }^{87} \mathrm{Sr} /{ }^{86} \mathrm{Sr}$ ratios and $\mathrm{H}_{2} \mathrm{~S}$ concentrations. 
T ABIE I. Sr, B, O, and $\mathrm{H}$ isotopic composition of Upper Smackover Formation waters. $\mathrm{O}$ and $\mathrm{H}$ isotopic composition in $0 / 00$. (Cl and $\mathrm{B}$ data from Moldovanyi and Walter, 1992)

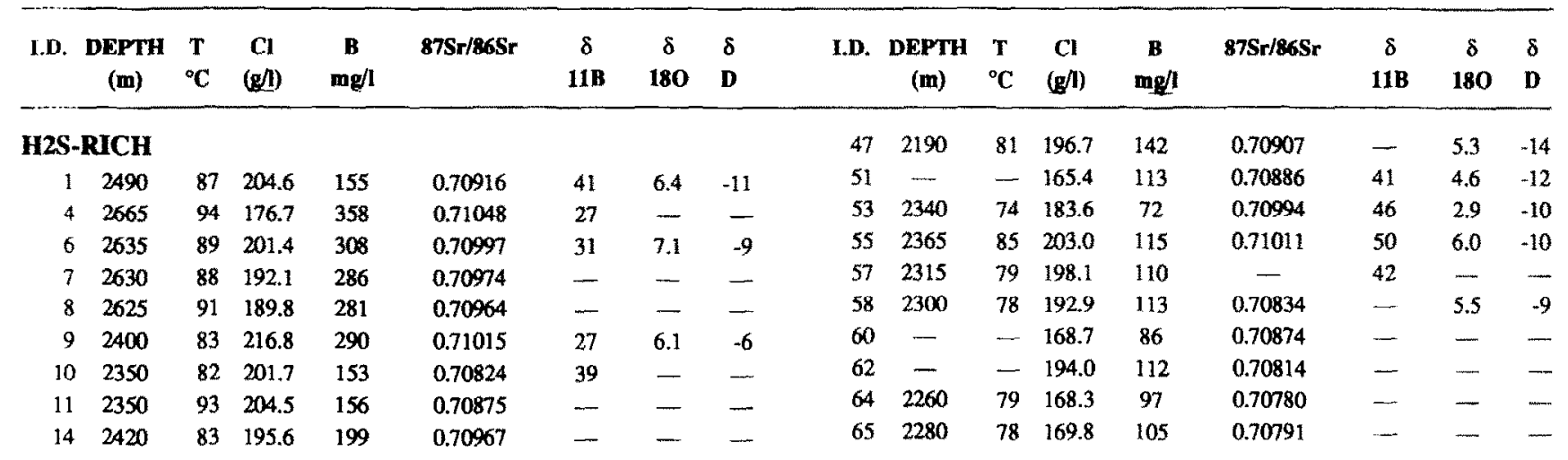

NORTHERN

$\begin{array}{lllll}17 & 2472 & 101 & 202.3 & 225\end{array}$

$\begin{array}{lllll}19 & 2509 & 83 & 201.4 & 186\end{array}$

$\begin{array}{lllll}22 & 2146 & 87 & 176.7 & 123\end{array}$

$23-\quad-171.4 \quad 111$

$\begin{array}{lllll}24 & 2115 & 79 & 171.2 & 104\end{array}$

$\begin{array}{lllll}25 & 2338 & 73 & 193.8 & 176\end{array}$

$\begin{array}{lllll}26 & 2330 & 77 & 196.1 & 178\end{array}$

$\begin{array}{lllll}31 & 2268 & 74 & 177.3 & 176\end{array}$

$\begin{array}{lllll}34 & 2180 & 80 & 166.6 & 126\end{array}$

$\begin{array}{lllll}35 & 2104 & 74 & 164.6 & 127\end{array}$

$\begin{array}{lllll}37 & 2245 & 61 & 176.6 & 168\end{array}$

$\begin{array}{lllll}39 & 2290 & 78 & 176.5 & 178\end{array}$

$41 \quad 1870$

$73 \quad 152.0 \quad 71$

0.70977

0.70962

0.70765

0.70875

0.70774

0.70908

0.70906

0.70884

0.70839

0.70809

0.70933

0.70935

0.70743

0.70754

\section{NORTHWESTERN}

$\begin{array}{rrrrcrrrr}* 43 & - & - & 193.1 & 182 & 0.71044 & 40 & - & - \\ * 44 & 2300 & 84 & 71.3 & 70 & 0.71071 & \ldots & \cdots & - \\ 46 & 1805 & 64 & 172.9 & 95 & 0.70828 & 43 & 4.4 & -13\end{array}$

$\begin{array}{rrrrrcrrr}67 & 1355 & 61 & 94.4 & 35 & 0.70859 & 50 & 0.2 & -19 \\ 70 & 1325 & 51 & 95.2 & 38 & 0.70855 & - & 0.4 & -25 \\ 73 & - & - & 132.0 & 57 & - & - & 3.7 & -26 \\ 75 & 1710 & 71 & 130.0 & 65 & 0.70786 & 45 & 2.8 & -22\end{array}$

\section{EASTERN}

$\begin{array}{lllllllll}78 & 1850 & - & 135.8 & 94 & 0.70935 & 47 & 4.4 & -18\end{array}$

\section{SOUTHERN}

\begin{tabular}{rrrrrrrrr}
79 & 3225 & 93 & 164.6 & 126 & 0.70869 & - & 5.7 & -12 \\
81 & 3245 & 104 & 174.6 & 106 & 0.70801 & - & - & - \\
83 & 3065 & 93 & 166.4 & 116 & 0.70886 & - & 6.2 & -17 \\
84 & 3055 & 98 & 152.0 & 108 & 0.70833 & - & - & - \\
85 & 3045 & 99 & 161.7 & 128 & 0.70852 & - & - & - \\
86 & 2765 & 89 & 161.6 & 112 & 0.70873 & - & 5.9 & -18 \\
87 & 2755 & 93 & 165.3 & 110 & 0.70867 & - & - & - \\
88 & - & - & 170.3 & 129 & 0.70843 & 34 & 7.4 & -15 \\
\hline
\end{tabular}

* Samples from siliciclastic reservoir associated facies.

As a group, $\mathrm{H}_{2} \mathrm{~S}$-free brines are somewhat less radiogenic and more homogeneous in their $\mathrm{Sr}$ isotope composition than $\mathrm{H}_{2} \mathrm{~S}$-rich brines, and do not exhibit a regional gradient (Fig $4 \mathrm{~b})$. As the frequency plot in Fig. $4 \mathrm{~b}$ indicates, most ${ }^{87} \mathrm{Sr} /$ ${ }^{86} \mathrm{Sr}$ ratios in $\mathrm{H}_{2} \mathrm{~S}$-free brines fall in the range between 0.7085 to 0.7090 . Two samples from east Texas and west Arkansas (\#43 and \#44 in Table 1) have unusually elevated ${ }^{87} \mathrm{Sr} /{ }^{86} \mathrm{Sr}$ ratios ( 0.71044 and 0.71071 , respectively) for $\mathrm{H}_{2} \mathrm{~S}$-free brines. Such radiogenic values likely reflect enhanced water-rock interactions with siliciclastic reservoirs known to be present in the Smackover Formation at these locations. Because of their intimate association with siliciclastics rather than oolitic carbonate reservoirs, these two water samples are excluded from further discussion.

Two-component mixing and endmember water compositions can be evaluated using plots of ${ }^{87} \mathrm{Sr} /{ }^{86} \mathrm{Sr}$ versus the inverse of $\mathrm{Sr}$ concentration (1/Sr; i.e., FAURE, 1986). Such a plot of Smackover Formation water data (Fig. 6) is not suggestive of two-component mixing. In fact, Sr concentrations in $\mathrm{H}_{2} \mathrm{~S}$-free and $\mathrm{H}_{2} \mathrm{~S}$-rich formation waters are relatively invariant with respect to the wide range of ${ }^{87} \mathrm{Sr} /{ }^{86} \mathrm{Sr}$ ratios. A few waters with lower salinities and lower $\mathrm{Sr}$ content cause considerable scatter in the plot of ${ }^{87} \mathrm{Sr} /{ }^{86} \mathrm{Sr}$ vs. $1 / \mathrm{Sr}$, but even normalizing $\mathrm{Sr}$ to $\mathrm{Cl}$ to eliminate potential dilution effects does not improve the relation.

Two-component mixing models assume that resulting mixtures are not altered after the mixing event has occurred (e.g., FaURE, 1986). Water-rock interactions involving addition or removal of $\mathrm{Sr}$ after mixing can disrupt a linear relation between ${ }^{87} \mathrm{Sr} /{ }^{86} \mathrm{Sr}$ and $1 / \mathrm{Sr}$ that would result from mixing two components. Smackover Formation brines contain 400 to $2950 \mathrm{mg} / \mathrm{L} \mathrm{Sr}$, more than ten times higher than predicted from theoretical seawater evaporation trajectories, and this enrichment most likely results from water-rock interaction with the host limestones and/or adjacent anhydrites and siliciclastic minerals (CARPENTER and TROUT, 1978; MOLDOVANYI and WALTER, 1992).

Strontium substitutes for $\mathrm{Ca}$ in calcite, barite, gypsum, and anhydrite, and is a major element in celestite and strontianite. Given the presence of these minerals in the host rocks (e.g., MOORE and DRUCKMAN, 1981; SWIRYDCZUK, 1988; MoldOVANYI et al., 1990), control on $\mathrm{Sr}$ concentration by mineral equilibria in Smackover Formation waters is reasonable. In fact, results of geochemical modeling of aqueous 

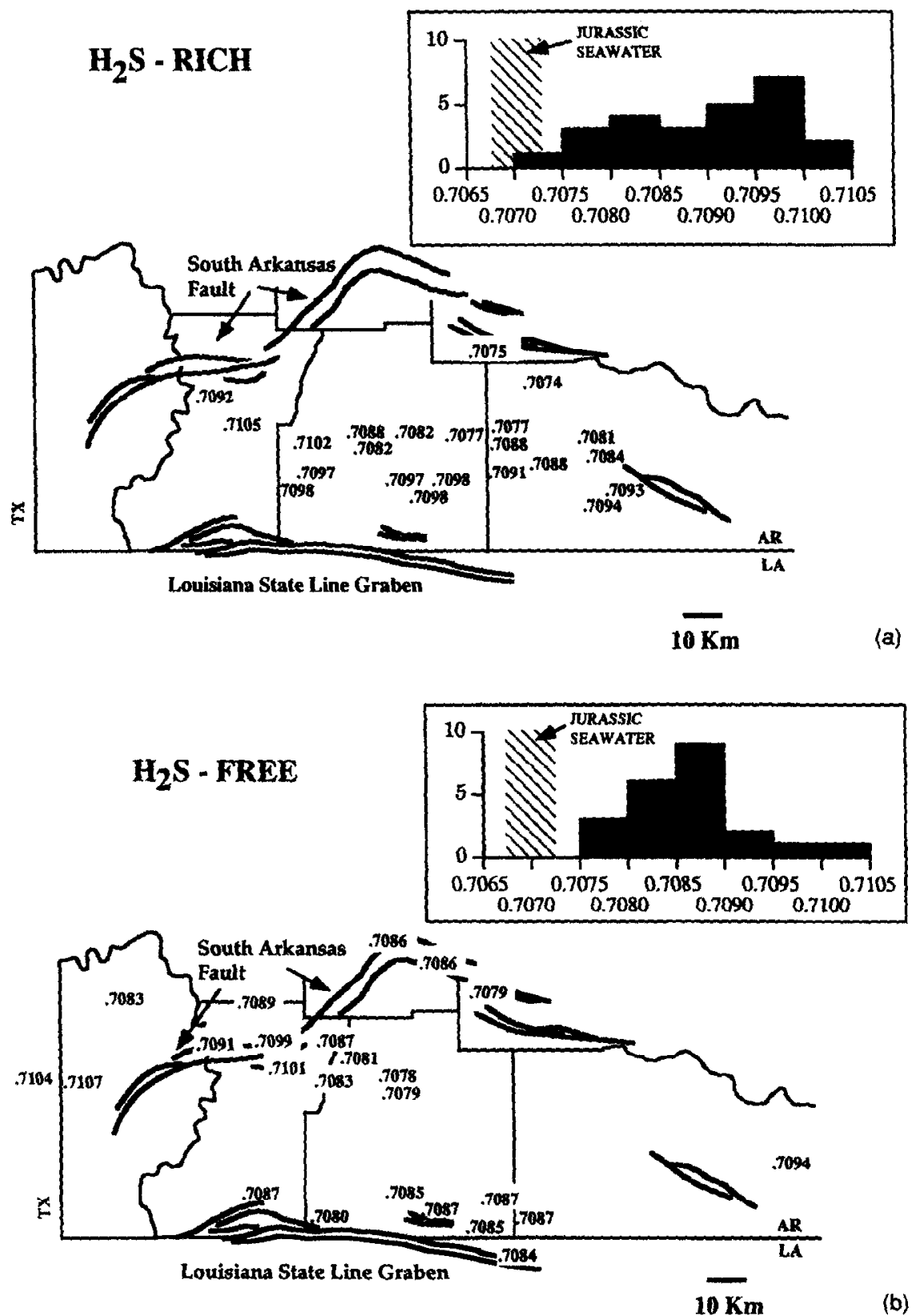

FIG. 4. Regional variations in ${ }^{87} \mathrm{Sr} /{ }^{86} \mathrm{Sr}$ ratios in $\mathrm{H}_{2} \mathrm{~S}$-rich (a) and $\mathrm{H}_{2} \mathrm{~S}$-free (b) brines from the Arkansas shelf. Mean ${ }^{87} \mathrm{Sr} /{ }^{86} \mathrm{Sr}$ ratios for Smackover brines are given in text. ${ }^{87} \mathrm{Sr} /{ }^{86} \mathrm{Sr}$ ratios for Jurassic-age marine carbonate range from 0.7068 to 0.7072 (BURKE et al., 1982).

species distributions using the code SOLMINEQ.88 (KHARAKA et al., 1988) indicate that Smackover Formation waters are near equilibrium with respect to anhydrite and celestite (MOLDOVANYI and WALTER, 1992).

Mixing in Smackover Formation brines is better evaluated by considering the relation between ${ }^{87} \mathrm{Sr} /{ }^{86} \mathrm{Sr}$ ratios and $\mathrm{B}$, $\mathrm{Li}, \mathrm{K}$, and $\mathrm{Rb}$ concentrations. These species ( $\mathrm{B}$ and alkali metals) are less likely to be affected by water-rock interactions with Upper Smackover Formation reservoir rocks since these elements are not involved in carbonate or sulfate mineral equilibria. Scatter diagrams of ${ }^{87} \mathrm{Sr} /{ }^{86} \mathrm{Sr}$ versus $\mathrm{B}$ and alkali metals show strong relations, but only in $\mathrm{H}_{2} \mathrm{~S}$-rich waters (Fig. 7). Sulfide-rich waters show a hyperbolic relation

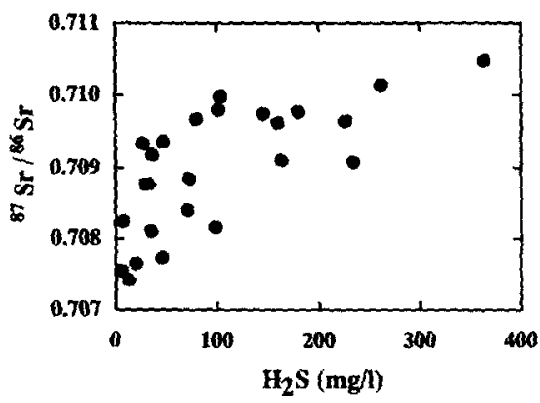

FiG. $5 .{ }^{87} \mathrm{Sr} /{ }^{86} \mathrm{Sr}$ ratios vs. $\mathrm{H}_{2} \mathrm{~S}$ concentrations in $\mathrm{H}_{2} \mathrm{~S}$-rich formation waters. ${ }^{87} \mathrm{Sr} /{ }^{86} \mathrm{Sr}$ ratios for Jurassic-age marine carbonate range from 0.7068 to 0.7072 (BURKE et al., 1982). 


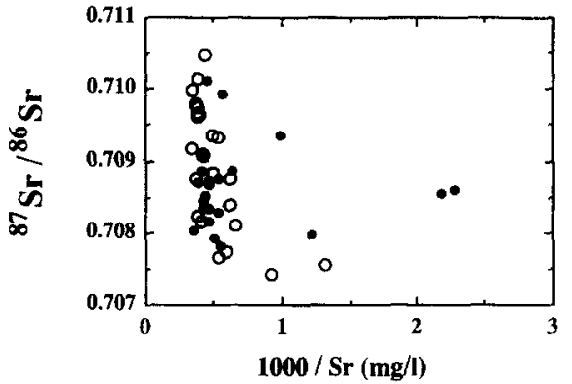

FIG. $6 .{ }^{87} \mathrm{Sr} /{ }^{86} \mathrm{Sr}$ ratios vs. $1 / \mathrm{Sr}$ showing absence of mixing relations in brines from oolitic carbonate reservoirs of the Smackover Formation. Open circles $=\mathrm{H}_{2} \mathrm{~S}$-rich and black circles $=\mathrm{H}_{2} \mathrm{~S}$-free formation waters. Radiogenic samples ( $\# 43$, \#44) from siliciclastic reservoirs in east Texas and west Arkansas have been excluded from the graph. ${ }^{87} \mathrm{Sr} /{ }^{86} \mathrm{Sr}$ ratios for Jurassic-age marine carbonate range from 0.7068 to 0.7072 (BURKE et al., 1982).

between ${ }^{87} \mathrm{Sr} /{ }^{86} \mathrm{Sr}$ ratios and $\mathrm{B}$ and alkali metal content, while $\mathrm{H}_{2} \mathrm{~S}$-free waters have uniformly low $\mathrm{B}$ and alkali metal content despite a wide range of ${ }^{87} \mathrm{Sr} /{ }^{86} \mathrm{Sr}$ ratios. The difference in trends between $\mathrm{H}_{2} \mathrm{~S}$-rich and $\mathrm{H}_{2} \mathrm{~S}$-free waters suggests that reservoirs across the Arkansas shelf have not been uniformly affected by the processes controlling B and alkali metal concentrations and $\mathrm{Sr}$ isotopic composition.

The positive correlation between $\mathrm{K}$ and ${ }^{87} \mathrm{Sr} /{ }^{86} \mathrm{Sr}$ values could result from recrystallization of $\mathrm{K}$-rich potash salts. Potash salts are unknown from the Louann Formation on the Arkansas shelf, but only a few wells have penetrated into the salt and little is known about its geochemistry. The lack of correlation between ${ }^{87} \mathrm{Sr} /{ }^{86} \mathrm{Sr}$ ratios and $\mathrm{Br}$, which would also be enriched by dissolution or recrystallization of potash salts, is also inconsistent with recrystallization. The strong relation among ${ }^{87} \mathrm{Sr} /{ }^{86} \mathrm{Sr}$ ratios and $\mathrm{H}_{2} \mathrm{~S}, \mathrm{~B}, \mathrm{Li}, \mathrm{K}$, and $\mathrm{Rb}$ concentrations points to a common source of $\mathrm{Sr}$ and these species, and suggests that waters are sourced from deeperseated evaporite and siliciclastic strata undergoing thermochemical sulfate reduction and diagenetic reactions at higher temperatures. Feldspars are common constituents of redbeds and their alteration could be a source of radiogenic $\mathrm{Sr}$ and $\mathrm{Rb}$ to formation waters (e.g., BOLES, 1982; LAND, 1987; RUSSELL et al., 1988). The significant enrichments in alkali metals, $\mathrm{B}$, and ${ }^{87} \mathrm{Sr}$ in $\mathrm{H}_{2} \mathrm{~S}$-rich formation waters in the vicinity of the South Arkansas Fault system suggest that these faults may be a conduit through which deeper-seated waters migrate into Upper Smackover reservoirs. The absence of the Louann Formation northwest of the fault zone places Smackover Formation waters in more direct proximity to the siliciclastics of the Norphlet and Eagle Mills formations. Gradients in $\mathrm{Sr}$ isotopic composition and trace element content suggest that waters enriched in ${ }^{87} \mathrm{Sr}, \mathrm{B}$, and alkali metals have migrated eastward, following permeable pathways approximately parallel to regional strike.

Heterogeneities in the ${ }^{87} \mathrm{Sr} /{ }^{86} \mathrm{Sr}$ ratios of $\mathrm{H}_{2} \mathrm{~S}$-free formation waters have no apparent regional relation to major and minor element geochemistry of the brines and cannot be modeled in terms of two-component mixing. The four $\mathrm{H}_{2} \mathrm{~S}$-free brine samples $(\# 47,53,55$, and 78 in Table 1$)$ with unusually radiogenic ${ }^{87} \mathrm{Sr} /{ }^{86} \mathrm{Sr}$ ratios $(0.7091$ to 0.7101$)$ are not markedly enriched in $\mathrm{B}$ or alkali metal content. These waters are from reservoirs associated with a segment of the South $\mathrm{Ar}$ kansas Fault in Lafayette County (Fig. 4b), suggesting that waters enriched in ${ }^{87} \mathrm{Sr}$, but not in $\mathrm{H}_{2} \mathrm{~S}, \mathrm{~B}$, and alkali metals, may have migrated along the fault zone at this location. The
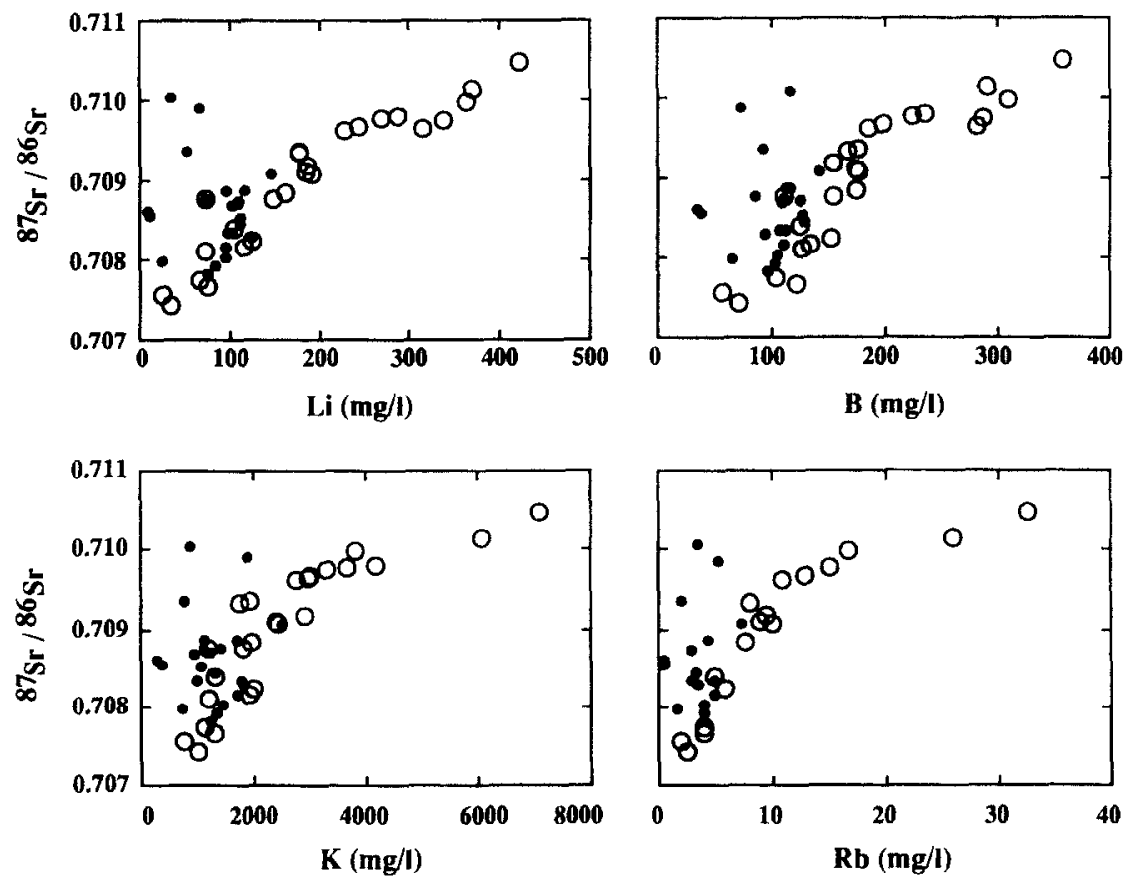

FIG. ${ }^{7}{ }^{87} \mathrm{Sr} /{ }^{86} \mathrm{Sr}$ ratios vs. $\mathrm{Li}, \mathrm{B}, \mathrm{K}$, and $\mathrm{Rb}$ concentrations in $\mathrm{H}_{2} \mathrm{~S}$-rich (open circles) and $\mathrm{H}_{2} \mathrm{~S}$-free waters (black circles) showing hyperbolic mixing relations in $\mathrm{H}_{2} \mathrm{~S}$-rich waters. Note that despite the similar range in ${ }^{87} \mathrm{Sr} /{ }^{86} \mathrm{Sr}$ ratios, $\mathrm{H}_{2} \mathrm{~S}$-frce brines generally have lower and more uniform $B$ and alkali metal contents. $\left(\mathrm{H}_{2} \mathrm{~S}\right.$-free samples $\# 43$ and $\# 44$ are not included in the diagrams). B and alkali metal concentrations from MOLDOVANYI and WALTER (1992). 
${ }^{87} \mathrm{Sr} /{ }^{86} \mathrm{Sr}$ ratios of formation waters from oolitic carbonate facies away from the fault are relatively invariant (mean $=0.70846 \pm 0.0004$ ). It is possible that variable degrees of local interactions with the clay-rich Lower Smackover may contribute to the smaller amplitude $\mathrm{Sr}$ isotopic heterogeneity in these brines.

Formation waters and diagenetic minerals in the Upper Smackover Formation in southwest Arkansas exhibit considerable heterogeneity in strontium isotopic compositions despite the relative homogeneity of the reservoir rock in which the waters and minerals are found. Geochemical relations and regional trends suggest that the $\mathrm{Sr}$ isotopic composition of these subsurface waters is controlled by carbonate and sulfate mineral diagenesis, and by mixing with waters which have interacted with silicate minerals in deeper and higher temperature regions of the sedimentary section, or with metamorphosed Paleozoic sediments. The results suggest that basinal waters, migrating through even a relatively small geographic area, are affected by processes acting on small spatial scales. The potential for small-scale spatial variations in ${ }^{87} \mathrm{Sr} /$ ${ }^{86} \mathrm{Sr}$ ratios has important implications for the application of $\mathrm{Sr}$ isotope systematics in mineral paragenetic studies which attribute variations in ${ }^{87} \mathrm{Sr} /{ }^{86} \mathrm{Sr}$ ratios to temporal trends. A non-uniform $\mathrm{Sr}$ reservoir present at a given time can seriously compromise assumptions involved in age-dating of diagenetic minerals. This is especially important in those studies where diagenetic minerals are correlated with host rocks and residual fluids in microscopic inclusions in order to date mineralization events and determine sources of fluids on a regional scale.

\section{BORON ISOTOPE SYSTEMATICS: BORON SOURCES AND BRINE EVOLUTION}

Boron contents and isotopic compositions of Smackover Formation brines are provided in Table 1 . Boron concentrations range by nearly a factor of 10 , from 35 to $350 \mathrm{mg} / \mathrm{L}$. For reference, seawater of normal salinity has a boron content of about $5 \mathrm{mg} / \mathrm{L}$; seawater evaporated to between halite and potash evaporite facies would contain between $\mathbf{4 8}$ and 170 $\mathrm{mg} / \mathrm{L} \mathrm{B}$.

Boron isotope composition also ranges widely in the Smackover Formation brines, from +26 to $+51 \%$ (Table 1). Modern ocean water has $\delta^{11} B$ value of $+40 \%$ (SPIVACK et al., 1987), as does seawater experimentally evaporated to potash salt stage (Land, unpubl. data). Thus, Smackover Formation brines are both isotopically enriched and depleted by significant amounts relative to seawater. The majority of the samples have a $B$ isotope composition heavier than seawater. There are still relatively few data on B contents and isotopic composition of subsurface or subaerial brines. Of the available data, only Dead Sea brines and some surficial Australian evaporated lakes have B isotope compositions heavier than modern ocean water (VENGOSH et al., 1989, 1991a,b); B isotope data from U.S. Gulf Coast formation waters (MACPHERSON and LAND, 1989; LAND and MACPHERSON, 1992), dominantly from Tertiary siliciclastic strata, tend to be significantly lighter than modern seawater (i.e., $<40 \%$ ). The same is true of $B$ isotope compositions of Illinois Basin brines throughout the stratigraphic section (STUEBER et al., 1993).
Boron isotope composition is plotted vs. inverse B content in Fig. 8. A mixing relation is evident, such that brines with higher $B$ contents have lower $\delta^{11} B$ values. $\mathrm{H}_{2} \mathrm{~S}$-rich brines all have $\delta^{11} B$ values significantly lower than those of $\mathrm{H}_{2} \mathrm{~S}$-free brines. There are variations in chloride content of Smackover brines from the southwest Arkansas shelf, brought about in part by meteoric recharge (MOLDOVANYI and WALTER, 1992). Thus, the mixing relation could be partially obscured by changes in B content. Nevertheless, it is apparent that Benriched brines with lower $\delta^{11} \mathrm{~B}$ values have mixed in variable proportions with brines relatively depleted in $\mathbf{B}$ and with $\delta^{11} \mathbf{B}$ values significantly enriched relative to modern ocean water.

Figure 9 shows the $\delta^{\mathrm{II}} \mathrm{B}$ values of Smackover brines plotted versus $\mathrm{Li}, \mathrm{K}, \mathrm{Rb}$, and $\mathrm{B}$ concentrations. Brines relatively depleted in ${ }^{11} \mathrm{~B}$ also are enriched significantly in alkali elements. Simple dissolution of borates cannot account for high B concentrations because borate minerals analyzed to date have $\delta$ " $B$ values near $+30 \%$ (SWIHART et al., 1986; MACPHERSON, $1989)$. When combined with the relations between alkali elements, $\mathrm{H}_{2} \mathrm{~S}$, and radiogenic $\mathrm{Sr}$, these data again suggest that the $\mathrm{H}_{2} \mathrm{~S}$-enriched brine endmember likely evolved in chemical and isotopic composition in contact with feldspars and clay minerals undergoing diagenesis at higher temperatures and deeper in the section. These brines may have migrated into Smackover Formation reservoirs on the Arkansas shelf via the South Arkansas Fault system.

Clearly, B has undergone both isotopic and concentration evolution in Smackover Formation brines. Variations in B content in sediment porewaters may result from multiple processes. Shales are often enriched in $B$ due to adsorption onto detrital clays in estuarine and marine environments (e.g., SPIVACK et al., 1987). During later stages of burial, the adsorbed B may be lost to solution as a result of shale dewatering and clay-mineral transformations, thereby increasing the $B$ concentration of the porewaters (e.g., HARDER, 1970; PERRY, 1972). Some B of crustal composition, contained in the crystal lattice of silicate minerals, may be released during dissolution. Boron may also be added to solution through interactions with borate minerals, such as boracite and danburite (MACPHERSON and LAND, 1989; SIMMONS, 1988). Alternatively, $B$ levels may decrease if $B$ is adsorbed or fixed onto the mineral lattice during clay mineral diagenesis (PERRY, 1972).

The Dead Sea brines have been interpreted as residual brines from marine halite deposits, enriched in $\mathrm{Br}$, which

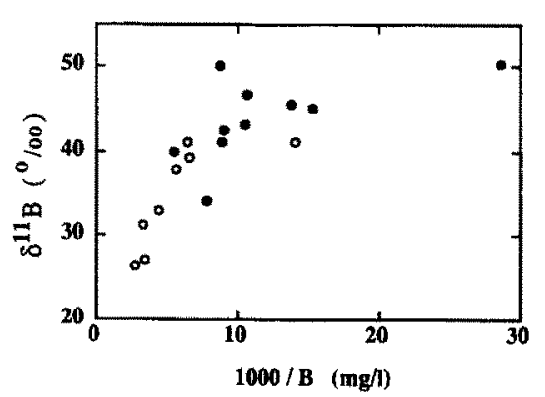

FiG. 8. $\delta^{11} \mathrm{~B}$ vs. inverse $\mathrm{B}$ content in $\mathrm{H}_{2} \mathrm{~S}$-rich (open circles) and $\mathrm{H}_{2} \mathrm{~S}$-free (closed circles) brines. $\delta^{11} \mathrm{~B}$ of normal seawater is $+40 \%$ (SPIVACK et al., 1987). Boron concentrations from MOLDOVANYI and WALTER (1992). 

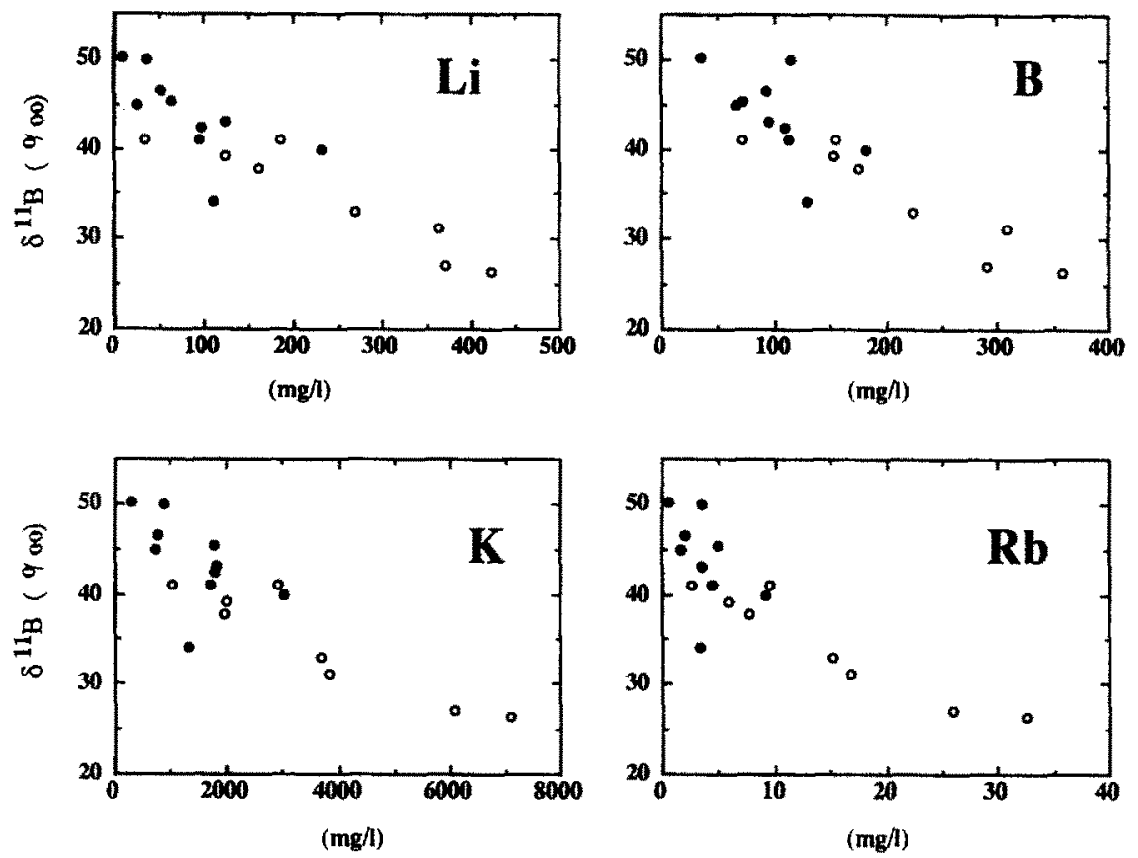

FIG. 9. $\delta^{11} \mathrm{~B}$ vs. $\mathrm{Li}, \mathrm{B}, \mathrm{K}$, and $\mathrm{Rb}$ concentrations in $\mathrm{H}_{2} \mathrm{~S}$-rich (open circles) and $\mathrm{H}_{2} \mathrm{~S}$-free (closed circles) brines. Alkali metal and B concentrations from MOLDOVANYl and WALTER (1992).

have undergone bacterial sulfate reduction and early dolomitization (SASS and STARINSKY, 1979; ZAK, 1974, 1980). VENGOSH et al. (1991a) suggest that Dead Sea brines are depleted in $\mathrm{B}$ content relative to their degree of evaporative concentration because of $B$ uptake onto clays with attendant boron isotope fractionation. Consistent with earlier work (SCHWARCZ et al., 1969; SPIVACK and EDMOND, 1987), isotopically light $B$ is preferentially adsorbed onto clays, resulting in water depleted in $\mathbf{B}$, but enriched in ${ }^{11} \mathrm{~B}$.

If Smackover Formation brines are considered to contain a primary evaporated seawater component, the degree of evaporation can be estimated assuming some conservative chemical species. Bromide in these brines is enriched above the degree of evaporation indicated from other proposed conservative parameters of seawater chemistry, such as the divalent cation function (CARPENTER, 1978). Nevertheless, on the assumption that $\mathrm{Br}$ remains the most nearly conservative element during seawater evaporation and water-rock interaction, we have normalized our B contents to $\mathrm{Br}$. Our data are compared with data from other natural waters in Fig. 10. Smackover Formation brines have $\mathrm{Br} / \mathrm{B}$ ratios up to four times those of modern seawater.

The Smackover Formation brine data in Fig. 10 form a better two-component mixing trend than the simple $1 / \mathrm{B}$ function plotted in Fig. 8 because the effect of meteoric dilution is removed. The position of Dead Sea brines at $\delta^{11} \mathrm{~B}$ values up to $+57 \%$ and $\mathrm{Br} / \mathrm{B}$ ratios between 60 and 140 appears consistent with the evaporatively concentrated, Bdepleted endmember of the two-component mixing trend, although there is considerable scatter in the mixing array.

Importantly, the " $B$-depleted, B-enriched endmember appears consistent with analyses reported by MACPHERSON and LAND (1989) and LAND and MACPHERSON (1992) for deep, saline formation waters from the Texas Gulf Coast section.
Many of these brines are of the $\mathrm{CaCl}_{2}$ type and are similar in overall chemistry to Smackover Formation waters. Thus, B enrichment in Smackover Formation brines could be similarly explained by release of ${ }^{10} \mathrm{~B}$ during higher temperature siliciclastic mineral diagenesis. This mechanism would also account for the other characteristics of this endmember, such as enrichments in $\mathrm{Li}, \mathrm{Rb}, \mathrm{K}$, and ${ }^{87} \mathrm{Sr}$, and is consistent with $\mathrm{H}_{2}$ S-enrichment by abiotic sulfate reduction at elevated temperatures (e.g., ORR, 1974, 1977; POWELL and MACQUEEN, 1984).

Redbeds of the Norphlet and Eagle Mills formations contain abundant feldspars and clay minerals and are a likely source of $\mathrm{K}, \mathrm{Li}, \mathrm{Rb}$, isotopically light $\mathrm{B}$, and radiogenic $\mathrm{Sr}$. Sulfates of the deep-seated Werner anhydrite are probably

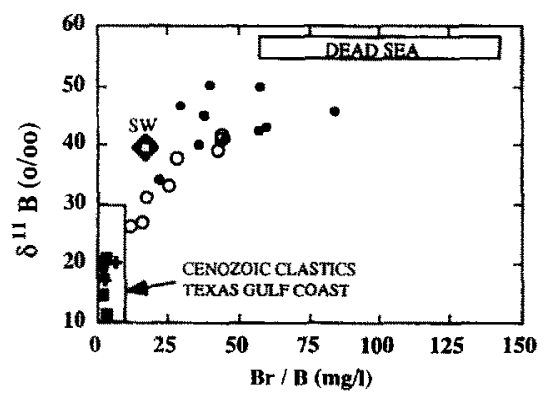

FiG. $10 . \delta^{11} \mathrm{~B}$ vs. $\mathrm{Br} / \mathrm{B}$ ratio in $\mathrm{H}_{2} \mathrm{~S}$-rich (open circles) and $\mathrm{H}_{2} \mathrm{~S}$ free (closed circles) Smackover Formation brines. Seawater (black diamond) is shown for reference. B-depleted Smackover brines are isotopically heavy, similar to Dead Sea brines (boxed area; from BENTOR, 1961; ZAK, 1974, 1980; VENGOSH et al., 1991a). Conversely, isotopically enriched samples are depleted in ${ }^{11} \mathrm{~B}$, consistent with deep saline Vicksburg Formation (cross) and Edwards Formation (open box) brines from the Texas Gulf Coast (from MACPHERSON and LAND, 1989). 
undergoing thermal reduction, and hence, are a likely source of $\mathrm{H}_{2} \mathrm{~S}$. Thus, waters circulating through these deeper formations interact with the rocks and become enriched in these species. The occurrence of highest ${ }^{87} \mathrm{Sr} /{ }^{86} \mathrm{Sr}$ ratios and $\mathrm{Li}$ and $\mathrm{K}$ concentrations at the northwestern end of this trend (Fig. 7) suggests that these "siliciclastic" fluids are possibly related to water migration along the more southwestern leg of the South Arkansas Fault. The tendency towards less radiogenic brine values in the south and east portions of the Arkansas shelf argues against the possibility of fluids entering via the Louisiana State Line Graben fault system.

Boron isotope systematics of Upper Jurassic Smackover Formation brines indicate that waters have been modified at various stages of the burial history. Porewaters of original marine composition could have been geochemically altered during shallow burial, as dense hypersaline Buckner Formation waters and possibly evolved brines from compaction of the underlying Louann Formation migrated into Upper Smackover Formation carbonates. Brine evolution has also been suggested from the REE composition of early calcite cements, which are enriched in heavy REEs and may have precipitated from waters depleted in light REEs, such as those associated with evaporite precipitation (MOLDOVANYI et al., 1990). In fact, it is conceivable that the Buckner depositional environment was much like the present-day Jordan Rift-Dead Sea setting, and that these fluids interacted with underlying evaporites and clastics much the same way that modern Dead Sea brines interact with associated sediments to produce the subsurface "rift valley" brines described by BENTOR (1969) and HARDIE (1990). The boron isotopic evolution was likely influenced by $\mathrm{B}$ depletion via uptake of ${ }^{10} \mathrm{~B}$ by clay minerals, as has been shown in Australian salt lakes (VENGOSH et al., 1991b) and the Dead Sea (Vengosh et al., 1991a).

Later, deeper burial processes have further modified the $B$ content and boron isotopic composition of Upper Smackover Formation porewaters, although the effect appears to be somewhat less widespread than the earlier diagenetic modification. Deeply circulating waters, enriched in $\mathrm{H}_{2} \mathrm{~S}, \mathrm{~B}, \mathrm{Li}$, $\mathrm{K}, \mathrm{Rb}$, and radiogenic $\mathrm{Sr}$ released during high-temperature siliciclastic diagenetic reactions, have mixed with the resident Smackover Formation waters. The degree of mixing, as evidenced by ${ }^{87} \mathrm{Sr} /{ }^{86} \mathrm{Sr}$ and $\delta^{11} \mathrm{~B}$ ratios, is variable and probably controlled by permeability of the reservoir. The deep-seated endmember brine must have been significantly depleted in "B to produce a $15-20 \%$ shift in $\delta^{11} \mathrm{~B}$ in the brines. Isotopically light $B$ was probably derived from clay mineral transformations, feldspars, or from metamorphosed basement rocks.

\section{OXYGEN AND HYDROGEN ISOTOPIC COMPOSITION: MIXING OF BRINES WITH METEORIC WATER AND WATER-ROCK INTERACTION}

Oxygen and hydrogen isotope compositions of Smackover Formation waters in southwest Arkansas (Table 1) are plotted relative to the meteoric water line (MWL) in Fig. $11 . \delta^{18} \mathrm{O}$ and $\delta \mathrm{D}$ values, ranging from $+0 \% 0$ to $+8 \%$ and $-26 \%$ to $-6 \%$, respectively, show systematic regional trends (Fig. 12). These values are generally closer to the oxygen and hydrogen isotopic composition of seawater (SMOW) than are subsurface waters in many higher latitude intracratonic basins where

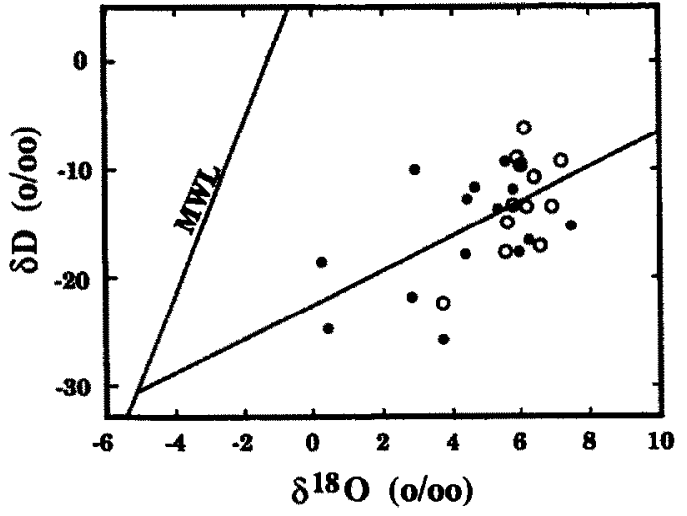

FIG. 11. $\delta^{18} \mathrm{O}$ vs. $\delta \mathrm{D}$ of Smackover Formation brines compared to SMOW and the global meteoric water line. Open circles $=\mathrm{H}_{2} \mathrm{~S}$ rich and black circles $=\mathrm{H}_{2}$ S-free waters from the present study. Regression line represents best fit for data in southwest Arkansas and intersects MWL at approximately $-5 \% \delta^{18} \mathrm{O}$ and $-30 \% \delta \mathrm{D}$.

$\delta \mathrm{D}$ values may be as low as $-130 \%$ (HITCHON and FRIEDMAN, 1969). Within the study area, samples having lightest $\delta^{18} \mathrm{O}$ and $\delta \mathrm{D}$ isotopic composition correlate with relatively shallow burial depths $(\leq 1750 \mathrm{~m})$ and relatively low formation temperatures (average $65^{\circ} \mathrm{C}$ ). These isotopically light waters are generally $\mathrm{H}_{2} \mathrm{~S}$-free or contain only minor amounts of $\mathrm{H}_{2} \mathrm{~S}$, have low TDS (as low as $150 \mathrm{~g} / \mathrm{L}$ as compared to 360 $\mathrm{g} / \mathrm{L}$ in most saline samples), and have mean $\delta^{18} \mathrm{O}$ and $\delta \mathrm{D}$ values of $+2 \pm 2 \%$ and $-23 \pm 3 \%$, respectively. The remaining samples, from deeper (up to $3250 \mathrm{~m}$ ) and hotter (up to $105^{\circ} \mathrm{C}$ ) reservoirs, are comprised of both $\mathrm{H}_{2} \mathrm{~S}$-rich and $\mathrm{H}_{2} \mathrm{~S}$-free formation waters and generally have more positive mean $\delta^{18} \mathrm{O}$ and $\delta \mathrm{D}$ values $(+6 \pm 1 \%$ and $-13 \pm 3 \%$, respectively).

Present-day meteoric waters in the U.S. Gulf Coast have average $\delta^{18} \mathrm{O}$ and $\delta \mathrm{D}$ ranges of approximately -3 to $-4 \%$ $\delta^{18} \mathrm{O}$ and -20 to $-23 \% \delta \mathrm{D}$ (CLAYTON et al., 1966; KHARAKA et al., 1987). Linear regression of Smackover Formation O and $\boldsymbol{H}$ isotope data for southwest Arkansas yields an intercept with the global meteoric water line of approximately $-5 \%$ $\delta^{18} \mathrm{O}$ and $-30 \% 0 \delta \mathrm{D}$ (Fig. 11). Given the scatter and the uncertainty of the fit $(r=0.6)$, this value is reasonably close to the composition present-day meteoric waters in the Gulf Coast.

Integration of elemental and stable isotope data, coupled with regional distribution of isotopically light waters in the vicinity of the South Arkansas Fault system, argue strongly for meteoric water mixing with the more saline endmember(s). We have already presented evidence that supports mixing within the saline brine endmember. $\delta^{11} \mathrm{~B}$-depleted, $\mathrm{H}_{2} \mathrm{~S}$-rich, and alkali-element-enriched fluids, flowing through deeper-seated sources undergoing higher-temperature diagenetic reactions, have apparently mixed into southwest Arkansas reservoirs. The isotopic composition of the meteoric endmember may be evaluated independently by integrating isotopic and elemental data. Regression of $\mathrm{Ca}$ vs. $\mathrm{Cl}$ concentrations shows that the brine compositions extrapolate to low $\mathrm{Ca}$ concentrations in the meteoric endmember (Fig. 13a). Meteoric waters should have relatively little $\mathrm{Ca}$ and $\mathrm{Cl}$ relative to the high $\mathrm{Ca}$ and $\mathrm{Cl}$ concentration of Smackover Formation 

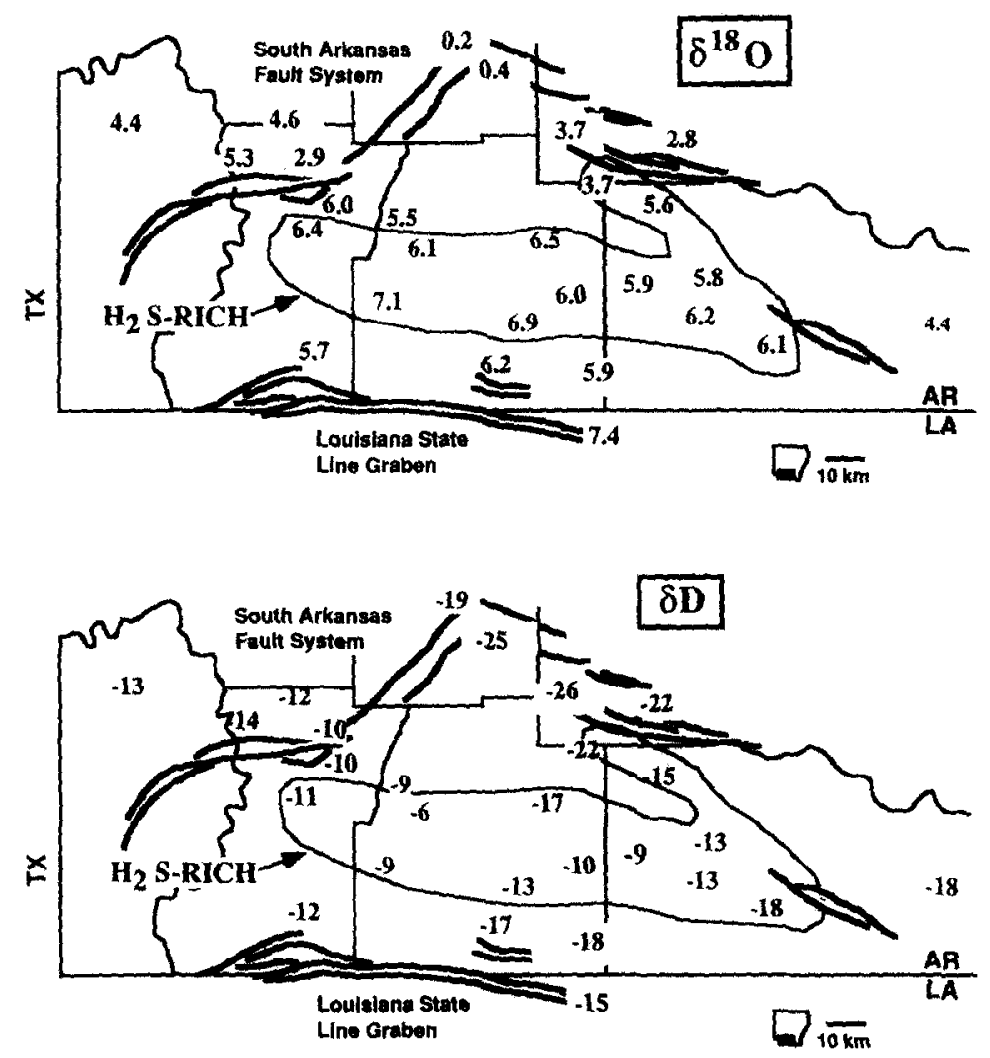

FIG. 12. Regional heterogeneities in $\delta^{18} \mathrm{O}$ (top) and $\delta \mathrm{D}$ (bottom) in $\mathrm{H}_{2} \mathrm{~S}$-rich and $\mathrm{H}_{2} \mathrm{~S}$-free formation waters. Lightest $\mathrm{O}$ and $\mathrm{H}$ isotopic composition occurs in northern reservoirs along the South Arkansas Fault. These northern reservoirs also have low $\mathrm{Cl}$ content and occur at relatively shallow depths (1750 $\mathrm{m}$ subsurface).

brines. At low $\mathrm{Ca}$ concentrations, the brines appear to contain approximately $45,000 \mathrm{mg} / \mathrm{L} \mathrm{Cl}$, likely due to halite dissolution during the downward migration of meteoric waters. Figures $13 \mathrm{~b}$ and $\mathrm{c}$ show the relation between $\mathrm{Ca}$ content and $\delta \mathrm{D}$ and $\delta^{18} \mathrm{O}$, respectively. Extrapolation of these data to low Ca concentration yields intercepts of $-4 \%$ for $\delta^{18} \mathrm{O}$ and $-36 \%$ for $\delta \mathrm{D}$. This oxygen and hydrogen isotopic composition for the meteoric endmember is very close to the composition obtained by extrapolation to the global MWL line (Fig. 11). The "saline" endmember appears to have a $\delta^{18} \mathrm{O}$ value of +5 to $+7 \%$ and a $\delta \mathrm{D}$ value of -5 to $-10 \%$ based on the compositional data in Fig. 13b,c.

Although the timing of meteoric recharge is difficult to constrain, volcanic activity, uplift, and erosion in the area during the Cretaceous makes this a plausible time for meteoric recharge (SALVADOR, 1987; BYerLy, 1991). Since that time, the Smackover Formation has undergone continuous burial so that meteoric influx would be more limited. However, it appears that some meteoric water has penetrated locally to great depths and has significantly altered the isotopic and chemical composition of Smackover Formation brincs in the immediate vicinity of the South Arkansas Fault. Meteoric infiltration subsequent to deposition of the Cretaceous Travis Peak sandstones has also been invoked to explain patterns and timing of sandstone diagenesis, including extensive quartz cementation (DUTTON and LAND, 1988).

The isotopic evolution of saline porewater within the Smackover Formation may have followed several paths. The stable isotopic composition of the isotopically heavy end- member could be related to evaporatively concentrated seawater. The stable isotopic composition of evaporating seawater defines a curved trajectory in $\delta^{18} \mathrm{O}$ and $\delta \mathrm{D}$ space (SOFER and GAT, 1975; HOLSER, 1979; PIERRE et al., 1984; KNAUTH and BEEUNAS, 1986). The exact position of the evaporation trajectory is difficult to model for ancient systems because climatic conditions (e.g., $\mathrm{T}^{\circ} \mathrm{C}$, humidity) are largely unknown.

Regardless of the original $\mathrm{H}_{2} \mathrm{O}$ source, interactions between water, carbonate, and siliciclastic minerals at high temperatures can shift $\delta^{18} \mathrm{O}$ and $\delta \mathrm{D}$ values and the magnitude of the shift will depend on the water-rock ratio (e.g., SUCHECKI and LAND, 1983; O'NEIL, 1987). These reactions generally tend to increase $\delta^{18} \mathrm{O}$ and decrease $\delta \mathrm{D}$. Because $\mathrm{O}$ isotope equilibrium between water and carbonate minerals can in theory be achieved at sedimentary temperatures (e.g., CLAYTON et al., 1966; KHARAK $A$ and CAROTHERS, 1986; LONGSTAFFE, 1987; O'NEn, 1987), and because $\delta \mathrm{D}$ values of formation waters may be influenced by other reactions involving isotopic exchange with $\mathrm{H}_{2} \mathrm{~S}$, hydrocarbons, and clay minerals, the potential effects of these processes on the oxygen and hydrogen isotopic composition of the saline Smackover Formation water must be considered.

The effect that carbonate water-rock equilibration has on the $\delta^{18} \mathrm{O}$ value of Smackover Formation waters can be evaluated from the published stable isotopic composition for grains, whole rock, and calcite cements from the study area (MOLDOVANY1 et al., 1990). The mean $\delta^{18} \mathrm{O}$ of the primary framework grains (ooids, rhodoliths) is $+27 \pm 1 \%$ (SMOW). 

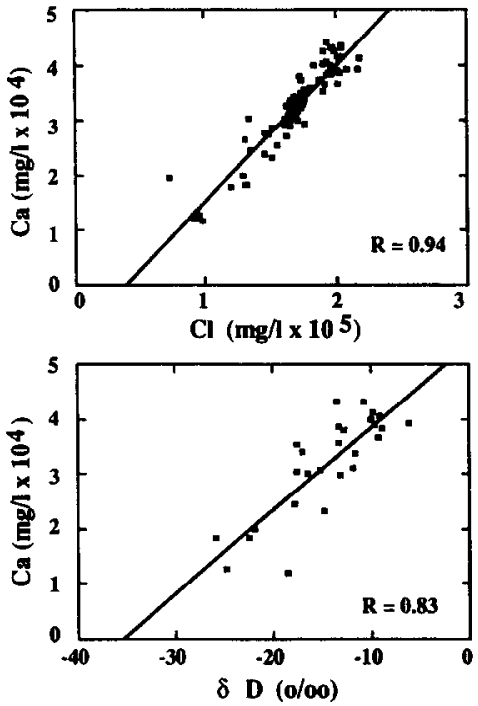

(b)

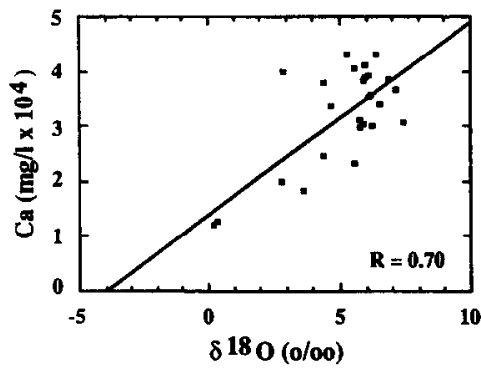

(c)

Fig. 13. Mixing between meteoric endmember waters and deeper saline brines as determined from (a) $\mathrm{Ca}$ vs. Cl concentrations; (b) $\mathrm{Ca}$ vs. $\delta^{18} \mathrm{O}$; and (c) Ca vs. $\delta \mathrm{D}$. Ca and $\mathrm{Cl}$ concentrations from MOLDOVANYI and WALTER (1992).

Whole-rock samples have a mean $\delta^{18} \mathrm{O}$ of $+26 \pm 1 \%$, largely because of varying amounts of late-stage poikilitic calcite cements ( $+23 \pm 0.5 \%$, SMOW). In Fig. 14, we present a plot of $\delta^{18} \mathrm{O}$ vs. temperature for formation water samples, superimposed on lines representing equilibrium conditions between formation water and calcite having $\delta^{18} \mathrm{O}$ values of framework grains $(27 \%)$ ) and poikilitic calcite (23\%) within Smackover Formation reservoir rocks. Many waters are not in equilibrium with respect to either grains or whole rock. Most waters could be considered to represent equilibrium between the bracketing values of late-stage calcspar cements and the bulk rock. However, it is questionable whether the stable isotopic compositions of calcspar cements buffer the formation waters, or whether the values simply reflect equilibrium with respect to the formation water which may have other controls on its composition. Thus, although the data do not represent simple rock buffering of water oxygen isotope composition, isotopic exchange with the carbonate host rock has modified water compositions significantly.

Clay minerals, $\mathrm{H}_{2} \mathrm{~S}$, and hydrocarbons are important hydrogen reservoirs. Experiments by O'NEIL and KHARAKA (1976) demonstrate that $\mathrm{H}$ isotopic exchange between detrital clays and formation waters can occur at relatively low temperatures. YeH (1980) and SUCHECKI and LAND (1983) report significant and progressive enrichment in $\delta \mathrm{D}$ of clays, and attendant decreases in $\delta \mathrm{D}$ of shale-buffered porewaters. However, $\mathrm{H}$ exchange does not appear to be significant in

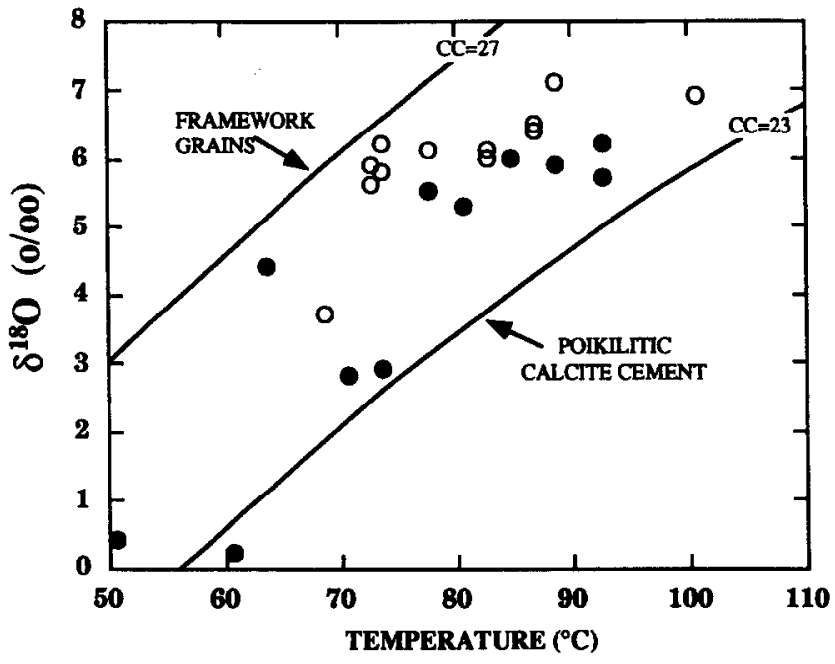

FIG. 14. $\delta^{18} \mathrm{O}$ vs. $T^{\circ} \mathrm{C}$ for $\mathrm{H}_{2} \mathrm{~S}$-rich (open circles) and $\mathrm{H}_{2} \mathrm{~S}$-free waters (black circles). Uncorrected bottom hole temperatures obtained from petrophysical well logs. Curves labeled $C C=27$ and $C C$ $=23$ represent equilibrium conditions between formation waters and framework grains having $\delta^{18} \mathrm{O}=+27 \pm 1 \%$, and poikilitic calcite having $\delta^{18} \mathrm{O}=+23 \pm 0.5 \%$, respectively.

other basinal settings with lower shale volumes (KHARAKA and CAROTHERS, 1986). Isotopic exchange between $\mathrm{H}_{2} \mathrm{~S}$ and hydrogen in formation waters has been found to be locally significant in the Western Canada sedimentary basin at very high $\mathrm{H}_{2} \mathrm{~S}$ concentrations (HITCHON and FRIEDMAN, 1969). A plot of $\delta \mathrm{D}$ vs. $\mathrm{H}_{2} \mathrm{~S}$ concentrations in Smackover Formation brines (Fig. 15) shows that $\delta \mathrm{D}$ is apparently related to $\mathrm{H}_{2} \mathrm{~S}$ content in sour brines. However, many Smackover Formation waters with high levels of $\mathrm{H}_{2} \mathrm{~S}$ have virtually the same $\delta \mathrm{D}$ value as samples with lower $\mathrm{H}_{2} \mathrm{~S}$ concentrations. A few $\mathrm{H}_{2} \mathrm{~S}$ rich brines are significantly enriched in deuterium but the same is true for some $\mathrm{H}_{2} \mathrm{~S}$-free brines (Table 1; Fig. 15). Thus, on a regional scale, $\delta \mathrm{D}$ values simply are not controlled by $\mathrm{H}_{2} \mathrm{~S}$ content. This is likely due to the relatively low mass of dissolved sulfide gas relative to the mass of water, the dominant hydrogen reservoir (HITCHON and FRIEDMAN, 1969; KHARAKA and CAROTHERS, 1986).

A summary diagram showing the potential for multiple evolution paths of the stable isotope composition of Smackover Formation waters is given in Fig. 16. The isotopically enriched endmember (also the saline endmember, see Figs.

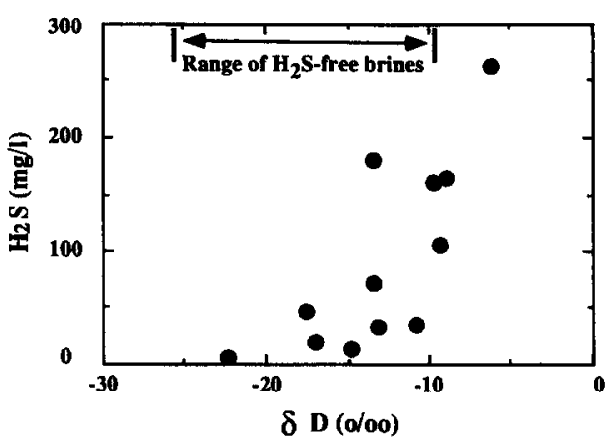

FIG. 15. $\delta D$ vs. $\mathrm{H}_{2} \mathrm{~S}$ concentrations in $\mathrm{H}_{2} \mathrm{~S}$-rich formation waters. Arrow represents the range of $\delta \mathrm{D}$ values for $\mathrm{H}_{2} \mathrm{~S}$-free waters. 


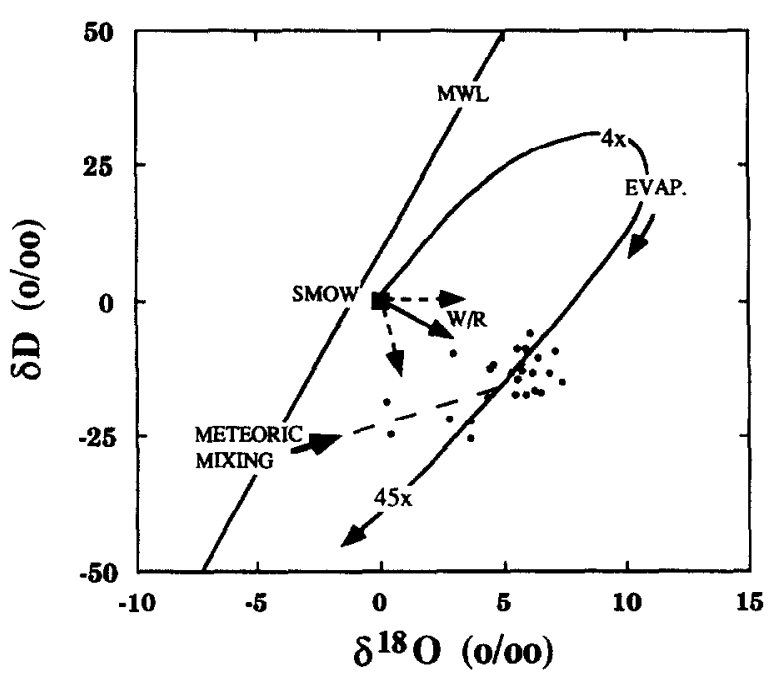

FIG. 16. Stable isotopic composition of Smackover Formation brines relative to SMOW, global meteoric water line (MWL), and a schematic "hooked" evaporation trajectory. Arrows indicate the expected shifts in $\delta^{18} \mathrm{O}$ and $\delta \mathrm{D}$ during evaporation, rock-water interactions, and meteoric invasion. Dotted line represents the regression of Smackover Formation brine data.

$13 \mathrm{~b}, \mathrm{c})$ could evolve from a variety of starting compositions and could follow various trajectories to its present-day composition. Water-rock interactions in carbonate or siliciclastic strata, depicted by radiating arrows, could involve water of SMOW-like compositions, evaporated seawater, or waters expelled from shales. Equilibration with siliciclastic and carbonate minerals would decrease $\delta \mathrm{D}$ and increase $\delta^{18} \mathrm{O}$. However, given the paucity of shales in basal strata in southwest Arkansas and given the salinity/stable isotope relations in these brines, it seems that effects on $\delta^{18} \mathrm{O}$ from water-rock interactions with carbonates would likely be of greater significance than the effects on $\delta \mathrm{D}$ values.

Later meteoric water invasion along faults, decreasing $\delta \mathrm{D}$, $\delta^{18} \mathrm{O}$, and $\mathrm{Cl}$ concentrations, is also indicated by the data. Importantly, it is less straightforward to invoke water-rock interactions solely with meteoric water, with subsequent evolution to its present composition through water-rock interactions. In that case, both $\delta \mathrm{D}$ and $\delta^{18} \mathrm{O}$ values would be expected to increase with progressive water-rock interactions, at odds with reported burial geochemical trends in shales (e.g., YEH, 1980; SUCHECKI and LAND, 1983). Perhaps coincidentally, the $\delta \mathrm{D}$ value of the most saline brine endmember (about $+10 \%$, Fig. 13c) corresponds to the evaporation trajectory positions within the halite facies of evaporative concentration of seawater, consistent with many other aspects of the elemental composition of these brines (MOLDOVANYI and WALTER, 1992).

\section{CONCLUSIONS}

Formation waters in Upper Jurassic Upper Smackover Formation carbonates exhibit striking variations in strontium, boron, oxygen, and hydrogen isotopic compositions within a small portion of the Gulf Coast basin in southwest Arkansas. The heterogeneities attest to the multiple geochemical processes which have influenced the isotopic composition of the formation waters. These processes potentially include evaporation of seawater to halite facies, meteoric water recharge, water-rock interactions during burial diagenesis, and mixing with hotter basinal brines undergoing reactions in deeperseated siliciclastic strata.

Strontium isotope ratios of Smackover Formation waters are extremely heterogeneous and are generally significantly more radiogenic than Jurassic seawater. Values of ${ }^{87} \mathrm{Sr} /{ }^{86} \mathrm{Sr}$ range from 0.70743 to 0.71071 and vary systematically across the study area. Most radiogenic ${ }^{87} \mathrm{Sr} /{ }^{86} \mathrm{Sr}$ ratios are found in $\mathrm{H}_{2} \mathrm{~S}$-rich brines and correlate with enrichments in $\mathrm{Li}, \mathrm{B}, \mathrm{K}$, and $\mathrm{Rb}$, consistent with input of radiogenic $\mathrm{Sr}$ and alkalis from siliciclastic sources. In contrast, $\mathrm{H}_{2} \mathrm{~S}$-free waters have a more homogeneous $\mathrm{Sr}$ isotopic composition which probably represents an "un-mixed" endmember composition, in part controlled by diagenetic interaction with marine Jurassic ${ }^{87} \mathrm{Sr}$ / ${ }^{86} \mathrm{Sr}$ of the carbonate host rock. Strontium concentrations are buffered by sulfate mineral equilibria and preclude application of the relation ${ }^{87} \mathrm{Sr} /{ }^{86} \mathrm{Sr}$ vs. $1 / \mathrm{Sr}$ as an accurate test of mixing phenomena.

Despite the absence of correlation between ${ }^{87} \mathrm{Sr} /{ }^{86} \mathrm{Sr}$ ratios and $1 / \mathrm{Sr}$, hyperbolic relations between $\mathrm{Sr}$ isotopic ratios and $\mathrm{H}_{2} \mathrm{~S}$, B, and alkali metals in $\mathrm{H}_{2} \mathrm{~S}$-rich waters indicate mixing with waters which have experienced siliciclastic diagenetic reactions and sulfate reduction at elevated temperatures. Fluids charged with ${ }^{87} \mathrm{Sr}, \mathrm{H}_{2} \mathrm{~S}, \mathrm{~B}$, and alkali metals probably gained access to the Smackover Formation reservoirs via the South Arkansas Fault zone and flowed toward the east along permeable pathways, mixing with the resident brine.

The boron isotopic composition of Smackover Formation brines in southwest Arkansas ranges from +26 to $+50 \%$. Brines enriched in $B$ relative to evaporation of seawater are depleted in ${ }^{11} \mathrm{~B}$, while those depleted in boron are enriched in ${ }^{~ 1} \mathrm{~B}$. Relative to seawater, the boron isotopic composition of the brines has been altered by the preferential removal or addition of the light isotope, ${ }^{10} \mathrm{~B}$, indicating that the dominant processes responsible for the isotopic composition of the brines involve boron derived from clay mineral transformations and / or crustal sources. Earliest diagenetic alteration of Smackover Formation carbonates and porewaters may have involved waters similar to Dead Sea brines in geochemical and boron isotopic composition. The Buckner depositional environment, from whence these waters may have been sourced, could have been very much like the modern Jordan Rift-Dead Sea area. A few Smackover Formation brine samples have $\delta^{11} \mathbf{B}$ similar to modern seawater and B concentrations which conform to predictions from evaporation trajectories. These could represent a less geochemically altered residual bittern.

The oxygen and hydrogen isotopic composition of Smackover Formation brines can be modeled in terms of an isotopically enriched brine and an isotopically-depleted meteoric endmember. The paucity of shales in the deep Gulf Coast sedimentary section in Arkansas suggests that local clay mineral diagenesis is not a major control on $\delta \mathrm{D}$ and $\delta{ }^{18} \mathrm{O}$ values of the isotopically enriched endmember. Likewise, interactions with $\mathrm{H}_{2} \mathrm{~S}$ do not appear to account for the variability in the $\delta \mathrm{D}$ values of these brines because $\mathrm{H}_{2} \mathrm{~S}$-free and $\mathrm{H}_{2} \mathrm{~S}$ rich brines have a similar range of $\delta \mathrm{D}$ values. Water-rock interactions with carbonates, however, have significantly af- 
fected the oxygen isotope composition. Thus, the $\delta \mathrm{D}$ value appears of greater import in elucidating trends among stable isotopic compositions and the solutes of these brines, but is difficult to interpret without knowing the flow path of the brines, and the minerals with which they have been in contact.

Acknowledgments-Acknowledgment is made to the Donors of the Petroleum Research Fund, American Chemical Society, for supporting this research (Grant PRF-18640-AC2). Additional support was provided by the National Science Foundation (Grant EAR8657180 ) and by Chevron Oil Company. We are grateful to Alden Carpenter and Bill Campbell for their valuable indoctrination to methods of field sampling and analysis of hot saline waters. We also thank Ted Huston for his assistance with laboratory analyses. Marlene Scott, Alan Stueber, Elizabeth Burton, and Cathy Connolly are thanked for their help in the field. Special thanks are extended to John Joyce (TXO Production Corporation), Jim Ball (Ethyl Corporation), and Ken Fritsche (Weiser Brown Oil Company) for making the Smackover fields in Arkansas available to us and for sharing local Smackover wisdom with us. Critiques by A. Carpenter, Z. Peterman, R. Spencer, and J. Wood greatly enhanced our manuscript.

\section{Editorial handling: R. J. Spencer}

\section{REFERENCES}

AWWILLER D. N. and MACK L. E. (1991) Diagenetic modification of Sm-Nd model ages in Tertiary sandstones and shales: Texas Gulf Coast. Geology 19, 311-314.

BENTOR Y. K. (1961) Some geochemical aspects of the Dead Sea and the question of its age. Geochim. Cosmochim. Acta 25, 239260.

BETHKE C. M. and MARSHAK S. ( 1990) Brine migration across North America-the plate tectonics of groundwater. Ann. Rev. Earth Planet. Sci. 18, 287-316.

BishOP W. F. ( 1967) Age of pre-Smackover Formations, North Louisiana and south Arkansas. AAPG Bull. 51, 244-250.

BisHOP W. F. (1973) Late Jurassic contemporaneous faults in North Louisiana and South Arkansas. AAPG Bull. 57, 858-877.

BOLES J. R. (1982) Active albitization of plagioclase, Gulf Coast Tertiary. Amer. J. Sci. 282, 165-180.

Brannon J. C., Podosek F. A., Viets J. G., Leach D. L., GoldHABER M., and ROWAN E. L. (1991) Strontium isotopic constraints on the origin of ore-forming fluids of the Viburnum Trend, southeast Missouri. Geochim. Cosmochim. Acta 55, 1407-1419.

Burke W. H., Denison R. E., HeTherington E. A., KoEPNick R. B., NELSON H. F., and OTTO J. B. (1982) Variation of seawater ${ }^{87} \mathrm{Sr} /{ }^{86} \mathrm{Sr}$ throughout Phanerozoic time. Geology 10, 516-519.

BYERLY G. R. (1991) Igneous activity. In The Geology of North America Volume J: The Gulf of Mexico Basin (ed. A. SALVADOR), pp. 91-108. Geological Society of America.

CARPENTER A. B. (1978) Origin and chemical evolution of brines in sedimentary basins. In Thirteenth Industrial Minerals Forum (ed. K. S. Johnson and J. R. Russell), Okla. Geol. Surv. Circ. 79, 60-77.

Carpenter A. B. and Trout M. L. (1978) Geochemistry of bromide-rich brines of the Dead Sea and southern Arkansas. In Thirteenth Industrial Minerals Forum (ed. K. S. JoHNSON and J. R. Russell); Okla. Geol. Surv. Circ. 79, 78-88.

Carpenter A. B., Trout M. L., and Picket E. E. (1974) Preliminary report on the origin and chemical evolution of lead- andzinc-rich oil field brines in central Mississippi. Econ. Geol. 69, 1191-1206.

CASAS E. and LowEnSTEIN T. K. (1989) Diagenesis of saline pan halite: Comparison of petrographic features of Modern, Quaternary and Permian halites. J. Sediment. Petrol. 59, 724-739.

Chaudhur S. (1978) Strontium isotopic composition of several oilfield brines from Kansas and Colorado. Geochim. Cosmochim. Acta 42, 329-331.

Chaudhuri S., Broedel V., and Clauer N. (1987) Strontium isotopic evolution of oil-field waters from carbonate reservoir rocks in Bindley Field, central Kansas, U.S.A. Geochim. Cosmochim. Acta 51, 45-53.

CHIMENE C. A. (1976) Upper Smackover reservoirs, Walker Creek Field area, Lafayette and Columbia Counties, Arkansas. In North American Oil and Gas Fields (ed. J. BRAUNSTEIN); AAPG Mem. 24, 177-204.

Clayton R. N., Friedman I., Graf D. L., Mayeda T. K., MeEnts W. F., and SHIMP N. F. (1966) The origin of saline formation waters: 1. Isotopic composition. J. Geophys. Res. 71, 3869-3882.

Collins A. G. (1974) Geochemistry of liquids, gases, and rocks from the Smackover Formation. US Bur. Mines Rept. of Investigations 7897.

CoLlins S. E. (1980) Jurassic Cotton Valley and Smackover reservoir trends, east Texas, north Louisiana, and south Arkansas. $A A P G$ Bull. 64, 1004-1013.

DickINSON K. A. (1968) Upper Jurassic Stratigraphy of some adjacent parts of Texas, Louisiana, and Arkansas. U.S. Geol. Surv. Prof. Pap. 594-E.

DUTTON S. P. and LAND L. S. (1988) Cementation and burial history of a low-permeability quartzarenite, Lower Cretaceous Travis Peak Formation, East Texas. GSA Bull. 100, 1271-1282.

DWORKIN S. I. (1991) Dissimilar diagenetic histories of Smackover Sandstones, Gulf of Mexico, U.S.A. Ph.D. dissertation, Univ. Texas, Austin.

EPSTEIN S. and MAYEDA T. K. (1953) Variation of ${ }^{18} \mathrm{O}$ content of waters from natural sources. Geochim. Cosmochim. Acta 4, $213-$ 224.

EUSTICE R. A. (1990) Petrography and geochemistry of the Jurassic Louann and Haynesville Formations, Clarke County, Southwestern Alabama. M.A. thesis, Univ. Texas, Austin.

FAURE G. (1986) Principles of Isotope Geology, 2d ed. John Wiley \& Sons.

GE S. and GARVEN G. (1989) Tectonically induced transient groundwater flow in foreland basins. In The Origin and Evolution of Sedimentary Basins and Their Energy and Mineral Resources (ed. R. A. PRICE); Amer. Geophys. Union Geophys. Monograph 48, 145-157.

GRAF D. L. (1982) Chemical osmosis, reverse chemical osmosis, and the origin of subsurface brines. Geochim. Cosmochim. Acta 46, 1431-1448.

GREEN M. (1989) Eylau, Tophat and West Texarkana (Smackover, Eagle Mills) Field Complex, Bowie County, Texas. In Occurrence of Oil and Gas in Northeast Texas, pp. 54-60. East Texas Geol. Soc.

Haley B. R., Glick E. E., Bush W. V., Clardy B. F., Stone C. G., WOODWARD M. B., and ZACHRY D. L. (1976) Geologic Map of Arkansas. The Arkansas Geological Commission and United States Geological Survey, scale 1:500,000.

HANOR J. S. (1987) Origin and Migration of Subsurface Sedimentary Brines; SEPM Lecture Notes for Short Course 21.

HARDER H. (1970) Boron content of sediments as a tool in facies analyses. Sediment. Geol. 4, 153-175.

HARDIE L. A. (1990) The roles of rifting and hydrothermal $\mathrm{CaCl}_{2}$ brines in the origin of potash evaporites: An hypothesis. Amer. $J$. Sci. 290, 43-106

HITCHON B. and FRIEDMAN I. (1969) Geochemistry and origin of formation waters in the western Canada sedimentary basin-I. Stable isotopes of hydrogen and oxygen. Geochim. Cosmochim. Acta 33, 1321-1349.

HOLSER W. (1979) Trace elements and isotopes in evaporites. In Marine Minerals (ed. R. G. BURNS); Rev. Mineral. 6, 295-346.

HOOPER E. C. D. (1991) Fluid migration along growth faults in compacting sediments. J. Petrol. Geol. 14, 161-180.

KESLER S. E., JONES L. M., and RUIZ J. (1988) Strontium isotopic geochemistry of Mississippi Valley-type deposits, East Tennessee: Implications for age and source of mineralizing brines. Geol. Soc. Amer. Bull. 100, 1300-1307.

KeSSEN K. M., WoOdRufF M. S., and GRANT N. K. ( 1981 ) Gangue mineral ${ }^{87} \mathrm{Sr} /{ }^{86} \mathrm{Sr}$ ratios and the origin of Mississippi Valley-Type mineralization. Econ. Geol. 76, 913-920.

KHARAKA Y. and CAROTHERS W. W. (1986) Oxygen and hydrogen isotope geochemistry of deep basin brines. In Handbook of Envi- 
ronmental Geochemistry, Vol. 2. (ed. P. FRITZ and J. CH. FONTES), pp. 305-360. Elsevier.

KHARAKA Y., BERRY F. A. F., and FrIEDMAN I. (1973) Isotopic composition of oil-field brines from Kettleman North Dome, California, and their geologic implications. Geochim. Cosmochim. Acta 37, 1899-1908.

Kharaka Y., Maest A. S., Carothers W. W., Law L. M., LaMOTHE P. J., and FRIES T. L. (1987) Geochemistry of metal-rich brines from central Mississippi Salt Dome basin, U.S.A. Appl. Geochem. 2, 543-561.

Kharaka Y., Gunter W. D., Aggarwal P. K., Perkins E. H., and DeBraAl J. D. (1988) SOlMINEQ.88: A computer program for geochemical modeling of water-rock interactions. USGS Water Resources Investigations Report 88-4227.

KNAUTH L. P. (1988) Origin and mixing history of brines, Palo Duro Basin, Texas, U.S.A. Appl. Geochem. 3, 455-474.

KNAUTH L. P. and BEEUNAS M. A. (1986) Isotope geochemistry of fluid inclusions in Permian halite with implications for the isotopic history of ocean water and the origin of saline formation waters. Geochim. Cosmochim. Acta 50, 419-433.

Knauth L. P., Kumar M. B., and Martinez J. D. (1980) Isotope geochemistry of water in Gulf Coast salt domes. J. Geophys. Res. $85,4863-4871$.

LAND L. S. (1987) The major ion chemistry of saline brines in sedimentary basins. In Physics and Chemistry of Porous Media II (ed. J. R. Banavar et al.); AIP Conference Proceedings, 160-179.

LAND L. S. and MACPHERSON G. L. (1989) Geochemistry of formation water. Plio-Pleistocene reservoirs, Offshore Louisiana. Trans. Gulf Coast Assoc. Geol. Soc. 39, 421-430.

LAND L. S. and MACPHERSON G. L. (1992) Origin of saline formation waters, Cenozoic section, Gulf of Mexico sedimentary basin. AAPG Bull. 76, 1344-1362.

LAND L. S. and PREZBINDOWSKI D. R. (1981) The origin and evolution of saline formation water, Lower Cretaceous carbonates, south-central Texas, USA. J. Hydrol. 54, 51-74.

LAND L. S., KuPECZ J. A., and MACK L. E. (1988) Louann Salt geochemistry (Gulf of Mexico Sedimentary Basin, U.S.A.): A preliminary synthesis. Chem. Geol. 74, 25-35.

Lange S., Chaudhuri S., and Clauer N. (1983) Strontium isotopic evidence for the origin of barites and sulfides from the Mississippi Valley-Type ore deposits in southeast Missouri. Econ. Geol 78, $1255-1261$

LONGSTAFFE F. J. (1987) Stable isotope studies of diagenetic processes. In Short Course in Stable Isotope Geochemistry of Low Temperature Fluids (ed. T. K. KYSER); Mineral Assoc. Canada Short Course 13, 187-257.

MACK L. E. (1990) Strontium as a tracer of diagenesis in Cenozoic sediments of the Northern Gulf of Mexico sedimentary basin. Ph.D. diss., Univ. Texas, Austin.

MACPHERSON G. L. ( 1989) Lithium, boron, and barium in formation waters and sediments, Northwestern Gulf of Mexico sedimentary basin. Ph.D. Thesis, University of Texas, Austin.

MACPHERSON G. L. and LAND L. S. (1989) Boron in saline brines, Gulf of Mexico Sedimentary Basin, U.S.A. 6th International Symposium Water-Rock Interactions, Malvern.

MCCAIG A. M. (1988) Deep fluid circulation in fault zones. Geology $16,867-870$.

MCNUTr R. H., FraPE S. K., and FRIT7. P. ( 1984) Strontium isotopic composition of some brines from the Precambrian Shield of Canada. Isotope Geosci. 2, 205-215.

MCNuTt R. H., Frape S. K., and Dollar P. (1987) A strontium, oxygen and hydrogen isotopic composition of brines, Michigan and Appalachian basins, Ontario and Michigan. Appl. Geochem. 2, 495-505

MedFord G. A., MAXWell R. J., and ARMSTrong R. L. (1983) ${ }^{87} \mathrm{Sr} /{ }^{86} \mathrm{Sr}$ ratio measurements on sulfides, carbonates, and fluid inclusions from Pine Point, Northwest Territories, Canada: An ${ }^{87} \mathrm{Sr} /{ }^{86} \mathrm{Sr}$ ratio increase accompanying the mineralization process. Econ. Geol. 78, 1375-1378.

Moldovanyi E. P. and Walter L. M. (1992) Regional trends in water chemistry, Smackover Formation, Southwest Arkansas: Geochemical and physical controls. AAPG Bull. 76, 864-894.

Moldovanyi E. P., Walter L. M., Brannon J. C., and Podosek
F. A. (1990) New constraints on carbonate diagenesis from integrated $\mathrm{Sr}$ and $\mathrm{S}$ isotopic and rare earth element data, Jurassic Smackover Formation, U.S. Gulf Coast. Appl. Geochem. 5, 449 470

MOORE C. H. and DRUCKMAN Y. (1981) Burial diagenesis and porosity evolution, Upper Jurassic Smackover, Arkansas and Louisiana. AAPG Bull. 65, 597-628.

Nakai S., Halliday A., Kesler S. E., and Jones H. D. (1990) $\mathrm{Rb}-\mathrm{Sr}$ dating of sphalerites from Tennessee and the genesis of Mississippi Valley type ore deposits. Nature 346, 354-357.

OLIVER J. (1986) Fluids expelled tectonically from orogenic belts: Their role in hydrocarbon migration and other geologic phenom ena. Geology 14, 99-102.

O'NeIL J. R. (1987) Preservation of H, C, and O isotopic ratios in the low temperature environment. In Short Course in Stable Isotope Geochemistry of Low Temperature Fluids (ed. T. K. KYSER); Mineral Assoc. Canada Short Course 13, 85-128.

O'NEIL J. R. and KHARAKA Y. K. (1976) Hydrogen and oxygen isotopic exchange between clay minerals and water. Geochim. Cosmochim. Acta 40, 241-246.

ORR W. L. (1974) Changes in sulfur content and isotopic ratios of sulfur during petroleum maturation: Study of Big Horn Basin Paleozoic oils. AAPG Bull. 58, 2295-2318.

ORR W. I. (1977) Geologic and geochemical controls on the distribution of hydrogen sulfide in natural gas. In Advances in Organic Geochemistry 1975 (ed. R. CAMPOS and J. GoNI); Proc. 7th Intl. Mtg. Org. Geochem., 571-597.

PERrY E. A., JR. (1972) Diagenesis and the validity of the boron paleosalinity technique. Amer. J. Sci. 272, 150-160.

PierRe C., ORTLIEB L., and Person A. (1984) Supratidal evaporitic dolomite at Ojo de Liebre lagoon: Mineralogical and isotopic arguments for primary crystallization. $J$. Sediment. Petrol. 54, 10491061

Popp B. N., Podosek F. A., Brannon J. C., ANderson T. F., and PIER J. ( 1986) ${ }^{87} \mathrm{Sr} /{ }^{86} \mathrm{Sr}$ ratios in Permo-Carboniferous seawater from analyses of well-preserved brachiopod shells. Geochim. Cosmochim. Acta 50, 1321-1328.

POWELl T. G. and MACQUEEN R. W. (1984) Precipitation of sulfide ores and organic matter: Sulfate reactions at Pine Point, Canada. Science 224, 63-66.

RitTFNHOUSE G (1967) Bromine in oil-field waters and its use in determining possibilities of origin of these waters. AAPG Bull. 51, 2430-2440.

Russell. C. W., Cowart J. B. and RusSell G. S. ( 1988) Strontium isotopes in brines and associated rocks from Cretaceous strata in the Mississippi Salt Dome Basin (southeastern Mississippi, U.S.A.). Chem. Geol. 74, 153-171.

SALVADOR A. (1987) Late Triassic-Jurassic Paleogeography and origin of Gulf of Mexico Basin. AAPG Bull. 65, 419-451.

SASS E. and STARINSKY A. (1979) Behaviour of strontium in subsurface calcium brines: Southern Israel and Dead Sea rift valley. Geochim. Cosmochim. Acta 43, 885-895.

SASSEN R. MOORE C. H., and MEENDSEN F. C. (1987) Distribution of hydrocarbon source potential in the Jurassic Smackover Formation. Org. Geochem. 11, 379-383.

SCHWARCZ H. P., AGYei E. K., and MCMUllen C. C. (1969) Boron isotopic fractionation during clay adsorption from sea water. Earth Planet. Sci. Lett. 6, 1-5.

Simmons W. B. (1988) Boron mineralization in the Louann Salt and Norphlet shale, Clarke County, Alabama. Trans. Gulf Coast Assoc. Geol. Soc. 38, 553-560.

SOFER Z. and GAT J. R. (1972) Activities and concentrations of oxygen-18 in concentrated aqueous salt solutions: analytical and geophysical implications. Earth Planet. Sci. Lett. 15, 232-238.

SOFER Z. and GAT J. R. (1975) The isotope composition of evaporating brines: Effect of the isotopic activity ratio in saline solutions. Earth Planet. Sci. Lett. 26, 179-186.

SPIVACK A. J. and EDMOND J. M. (1987) Boron isotope exchange between seawater and the oceanic crust. Geochim. Cosmochim. Acta 51, 1033-1043.

SpivaCK A. J., PAlmer M. R., and Edmond J. M. (1987) The sedimentary cycle of boron isotopes. Geochim. Cosmochim. Acta $\mathbf{5 1}$ 1939-1949. 
Starinsky A., Bielski M., Lazar B., Steinitz G., and RaAB M. (1983) Strontium isotope evidence on the history of oilfield brines, Mediterranean Coastal Plain, Israel. Geochim. Cosmochim. Acta 47, 687-695.

STOESSEL R. K. and MOORE C. H. ( 1983) Chemical constraints and origins of four groups of Gulf Coast reservoir fluids. AAPG Bull. 67, 896-906.

StUEber A. M. and WALTER L. M. (1991) Origin and chemical evolution of formation waters from Silurian-Devonian strata in the Illinois Basin. Geochim. Cosmochim. Acta 55, 309-325.

Stueber A. M., PushKar P., and Hetherington E. A. (1984) A strontium isotopic study of Smackover brines and associated solids, southern Arkansas. Geochim. Cosmochim. Acta 48, 1637-1649.

Stueber A. M., Pushkar P., and Hetherington E. A. (1987) A strontium isotopic study of formation waters from the Illinois basin, U.S.A. Appl. Geochem. 2, 477-494.

Stueber A. M., Walter L. M., Huston T. J., and Pushk ar P. (1993) Formation waters from Mississippian-Pennsylvanian reservoirs, Illinois basin, USA: Chemical and isotopic constraints on evolution and migration. Geochim. Cosmochim. Acta 57, 763784.

SUCHECKI R. and LAND L. S. ( 1983) Isotope geochemistry of burialmetamorphosed volcanogenic sediments, Great Valley sequence, northern California. Geochim. Cosmochim. Acta 47, 1487-1499.

SVERJENSKY D. A. (1984) Oil field brines as ore-forming solutions. Econ. Geol. 79, 23-37.

Swihart G. H., MOORe P. B., and Callis E. L. (1986) Boron iso- topic composition of marine and nonmarine borates. Geochim. Cosmochim. Acta 50, 1297-1301.

SWIRYDCZUK K. (1988) Mineralogical control on porosity type in Upper Jurassic Smackover ooid grainstones, southern Arkansas and northern Louisiana. J. Sediment. Petrol. 58, 339-347.

TrouT M. L. (1974) Origin of bromide-rich brines in southern Arkansas. M. A. thesis, Univ. Missouri, Columbia.

Vengosh A., Chivas A. R., and MCCulloch M. T. (1989) Direct determination of boron and chlorine isotopic compositions in geological materials by negative thermal-ionization mass spectrometry. Chem. Geol. 79, 333-343.

Vengosh A., Starinsky A., Kolodny Y., and Chivas A. R. (1991a) Boron isotope geochemistry as a tracer for the evolution of brines and associated hot springs from the Dead Sea, Israel. Geochim. Cosmochim. Acta 55, 1689-1695.

Vengosh A., Chivas A. R., McCulloch M. T., Starinsky A., and KoloDNY Y. (199lb) Boron isotope geochemistry of Australian Lakes. Geochim. Cosmochim. Acta 55, 2591-2606.

YEH H. W. (1980) D/H ratios and late-stage dehydration of shales during burial. Geochim. Cosmochim. Acta 44, 341-352.

ZAK 1. (1974) Sedimentology and bromine geochemistry of marine and continental evaporites in the Dead Sea Basin. In Fourth Intl. Symp. on Salt. (ed. A. H. COOGAN), vol. 1, pp. 349-361. Northern Ohio Geological Society.

ZAK I. (1980) The geochemical evolution of the Dead Sea. In Fifth Intl. Symp. on Salt (ed. A. H. CoOGAN), vol. 1, pp. 181-184. Northern Ohio Geol. Soc. 